\title{
Synthesis and Reactions of Five-Coordinate Mono- and Binuclear Thiocarbonyl-Alkenyl and Thioacyl Complexes of Ruthenium(II)
}

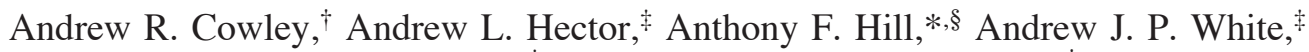 \\ David J. Williams, \\ Chemistry Research Laboratory, University of Oxford, Oxford, U.K., Department of Chemistry, \\ Imperial College, London, U.K., and Research School of Chemistry, Institute of Advanced Studies, \\ Australian National University, Canberra, Australian Capital Territory, Australia
}

Received May 24, 2007

\begin{abstract}
The reactions of $\left[\mathrm{RuHCl}(\mathrm{CS})\left(\mathrm{PPh}_{3}\right)_{3}\right]$ with $\mathrm{R}^{1} \mathrm{C} \equiv \mathrm{CR}^{2}\left(\mathrm{R}^{1}=\mathrm{R}^{2}=\mathrm{H}, \mathrm{Ph}, \mathrm{CO}_{2} \mathrm{Me} ; \mathrm{R}^{1}=\mathrm{H}, \mathrm{R}^{2}=\right.$ $\left.\mathrm{C}_{6} \mathrm{H}_{4} \mathrm{Me}-4 ; \mathrm{R}^{1}=\mathrm{C} \equiv \mathrm{CPh}, \mathrm{R}^{2}=\mathrm{Ph}\right)$ lead to the five- or six-coordinate $\left(\mathrm{R}^{1}=\mathrm{R}^{2}=\mathrm{CO}_{2} \mathrm{Me}\right) \sigma$-alkenyl complexes $\left[\mathrm{Ru}\left(\mathrm{CR}^{1}=\mathrm{CHR}{ }^{2}\right) \mathrm{Cl}(\mathrm{CS})\left(\mathrm{PPh}_{3}\right)_{2}\right]$, the stilbenyl derivative being also formed by thermolysis of $\left[\mathrm{RuCl}\left(\kappa^{2}-\mathrm{O}_{2} \mathrm{CH}\right)(\mathrm{CS})\left(\mathrm{PPh}_{3}\right)_{2}\right]$ in the presence of diphenylacetylene. These complexes rapidly react with carbon monoxide to provide the bidentate thioacyl complexes $\left[\mathrm{Ru}\left(\eta^{2}-\mathrm{SCCR}^{1}=\mathrm{CHR}{ }^{2}\right) \mathrm{Cl}(\mathrm{CO})\left(\mathrm{PPh}_{3}\right)_{2}\right]$ $\left(\mathrm{R}^{1}=\mathrm{R}^{2}=\mathrm{H}, \mathrm{Ph} ; \mathrm{R}^{1}=\mathrm{H}, \mathrm{R}^{2}=\mathrm{Ph} ; \mathrm{R}^{1}=\mathrm{C} \equiv \mathrm{CPh}, \mathrm{R}^{2}=\mathrm{Ph}\right)$ or the $\sigma$-alkenyl tautomer $\left[\mathrm{Ru}\left(\mathrm{CR}^{1}=\right.\right.$ $\left.\left.\mathrm{CHR}^{2}\right) \mathrm{Cl}(\mathrm{CO})(\mathrm{CS})\left(\mathrm{PPh}_{3}\right)_{2}\right]\left(\mathrm{R}^{1}=\mathrm{R}^{2}=\mathrm{CO}_{2} \mathrm{Me}\right)$, depending on the alkenyl substituent. The compound $\left[\mathrm{RuHCl}(\mathrm{CS})\left(\mathrm{PPh}_{3}\right)_{3}\right]$ reacts with $1 / 2$ equiv of 1,4-diethynylbenzene to provide the coordinatively unsaturated bimetallic species $\left[\left(\mathrm{Ph}_{3} \mathrm{P}\right)_{2}(\mathrm{SC}) \mathrm{ClRu}\left(\mathrm{CH}=\mathrm{CHC}_{6} \mathrm{H}_{4} \mathrm{CH}=\mathrm{CH}\right) \mathrm{RuCl}(\mathrm{CS})\left(\mathrm{PPh}_{3}\right)_{2}\right]$ in situ, which undergoes migratory insertion on addition of carbon monoxide to give the bis(thioacyl) species $\left[\left(\mathrm{Ph}_{3} \mathrm{P}\right)_{2}(\mathrm{OC}) \mathrm{ClRu}-\right.$ $\left.\left(\eta^{2}-\mathrm{SCCH}=\mathrm{CHC}_{6} \mathrm{H}_{4} \mathrm{CH}=\mathrm{CHCS}-\eta^{2}\right) \mathrm{RuCl}(\mathrm{CO})\left(\mathrm{PPh}_{3}\right)_{2}\right]$. On reaction with BSD $(2,1,3$-benzoselenadiazole $)$, $\left[\mathrm{Ru}\left(\mathrm{CH}=\mathrm{CH}_{2}\right) \mathrm{Cl}(\mathrm{CS})\left(\mathrm{PPh}_{3}\right)_{2}\right]$ gives $\left[\mathrm{Ru}\left(\mathrm{CH}=\mathrm{CH}_{2}\right) \mathrm{Cl}(\mathrm{CS})(\mathrm{BSD})\left(\mathrm{PPh}_{3}\right)_{2}\right]$ without migration of the alkenyl group. The complex $\left[\mathrm{RuHCl}(\mathrm{CS})(\mathrm{BSD})\left(\mathrm{PPh}_{3}\right)_{2}\right]$ results from the reaction of $\left[\mathrm{RuHCl}(\mathrm{CS})\left(\mathrm{PPh}_{3}\right)_{3}\right]$ and $\mathrm{BSD}$, and this complex hydroruthenates alkynes cleanly to provide $\left[\mathrm{Ru}\left(\mathrm{CR}^{1}=\mathrm{CHR}^{2}\right) \mathrm{Cl}(\mathrm{CS})(\mathrm{BSD})\left(\mathrm{PPh}_{3}\right)_{2}\right]$, carbonylation of which leads to loss of BSD and formation of $\left[\mathrm{Ru}\left(\eta^{2}-\mathrm{SCCR}^{1}=\mathrm{CHR}{ }^{2}\right) \mathrm{Cl}(\mathrm{CO})\left(\mathrm{PPh}_{3}\right)_{2}\right]$. Addition of carboxylate donors $\mathrm{R}^{\prime} \mathrm{CO}_{2}{ }^{-}\left(\mathrm{R}^{\prime}=\mathrm{H}, \mathrm{Fc}\right)$ to the complexes $\left[\mathrm{RuRCl}(\mathrm{CS})\left(\mathrm{PPh}_{3}\right)_{2}\right](\mathrm{R}=$ $\left.\mathrm{CH}=\mathrm{CH}_{2}, \mathrm{C}(\mathrm{C} \equiv \mathrm{CPh})=\mathrm{CHPh}\right)$ results in the complexes $\left[\mathrm{RuR}\left(\kappa^{2}-\mathrm{O}_{2} \mathrm{CR}^{\prime}\right)(\mathrm{CS})\left(\mathrm{PPh}_{3}\right)_{2}\right]$, without migratory insertion. A trimetallic example, $\mathrm{Fe}\left[\mathrm{C}_{5} \mathrm{H}_{4} \mathrm{CO}_{2} \mathrm{Ru}\{\mathrm{C}(\mathrm{C} \equiv \mathrm{CPh})=\mathrm{CHPh}\}(\mathrm{CS})\left(\mathrm{PPh}_{3}\right)_{2}\right]_{2}$, was formed in the corresponding reaction with $1,1^{\prime}$-ferrocenedicarboxylic acid and $\mathrm{Et}_{3} \mathrm{~N}$. The crystal structures of the complexes $\left[\mathrm{Ru}(\mathrm{CPh}=\mathrm{CHPh}) \mathrm{Cl}(\mathrm{CS})\left(\mathrm{PPh}_{3}\right)_{2}\right], \quad\left[\mathrm{Ru}\{\mathrm{C}(\mathrm{C} \equiv \mathrm{CPh})=\mathrm{CHPh}\} \mathrm{Cl}(\mathrm{CS})\left(\mathrm{PPh}_{3}\right)_{2}\right], \quad\left[\mathrm{Ru}\left\{\eta^{2}-\mathrm{SCC}-\right.\right.$ $\left.(\mathrm{C} \equiv \mathrm{CPh})=\mathrm{CHPh}\} \mathrm{Cl}(\mathrm{CO})\left(\mathrm{PPh}_{3}\right)_{2}\right],\left[\mathrm{Ru}\{\mathrm{C}(\mathrm{C} \equiv \mathrm{CPh})=\mathrm{CHPh}\}\left(\kappa^{2}-\mathrm{O}_{2} \mathrm{CFc}\right)(\mathrm{CS})\left(\mathrm{PPh}_{3}\right)_{2}\right]$ and $\mathrm{Fe}\left[\mathrm{C}_{5} \mathrm{H}_{4} \mathrm{CO}_{2^{-}}\right.$ $\left.\mathrm{Ru}\{\mathrm{C}(\mathrm{C} \equiv \mathrm{CPh})=\mathrm{CHPh}\}(\mathrm{CS})\left(\mathrm{PPh}_{3}\right)_{2}\right]_{2}$ are reported.
\end{abstract}

\section{Introduction}

There has been considerable interest in the reactions of the complexes $\left[\mathrm{RuHCl}(\mathrm{CO})\left(\mathrm{PPh}_{3}\right)_{2}(\mathrm{~L})\right]\left(\mathrm{L}=\mathrm{PPh}_{3}\right.$, dimethylpyrazole, pyridine, 2,1,3-benzoselenadiazole) with alkynes, which lead to facile hydroruthenation of the $\mathrm{C} \equiv \mathrm{C}$ triple bond and the formation of $\sigma$-alkenyl complexes (Scheme 1). ${ }^{1}$ Similar reactivity has also been observed in the reactions of $[\mathrm{RuHCl}(\mathrm{CO})$ $\left.\left(\mathrm{PPh}_{3}\right)_{3}\right]$ and $\left[\mathrm{RuHI}(\mathrm{CO})(\mathrm{NCMe})\left(\mathrm{PPh}_{3}\right)_{2}\right]$ with phosphaalkynes, leading to reactive phosphaalkenyl complexes that are precursors to a range of unsaturated organophosphorus ligands. ${ }^{3}$

* To whom correspondence should be addressed. E-mail: a.hill@anu.edu.au (A.F.H.), james.wilton-ely@chem.ox.ac.uk (J.D.E.T.W.-E.).

$\dagger$ University of Oxford.

Imperial College.

$\S$ Australian National University.

(1) (a) Torres, M. R.; Vegas, A.; Santos, A. J. Organomet. Chem. 1986 309, 169. (b) Romero, A.; Santos, A.; Vegas, A. Organometallics 1988, 7, 1988. (c) Torres, M. R.; Perales, A.; Loumrhari, H.; Ros, J. J. Organomet. Chem. 1990, 385, 379. (d) Loumrhari, H.; Ros, J.; Torres, M. R.; Perales, A. Polyhedron 1990, 9, 907. (e) Montoya, J.; Santos, A.; Echavarren, A. M.; Ros, J. J. Organomet Chem. 1990, 390, C57. (f) Torres, M. R.; Perales, A.; Loumrhari, H.; Ros, J. J. Organomet. Chem. 1990, 384, C61. (g) Hill, A. F.; Melling, R. P. J. Organomet. Chem. 1990, 396, C22. (h) Loumrhari, H.; Matas, L.; Ros, J.; Torres, M. R.; Perales, A. J. Organomet. Chem. 1991, 403, 373. (i) Hill, A. F.; Melling, R. P.; Thompsett, A. R. J. Organomet. Chem. 1991, 402, C8. (j) Romero, A.; Santos, A.; López, J.; Echavarren, A. M. J. Organomet. Chem. 1990, 391, 219.
Scheme 1. Alkyne Hydrometalation by $\left[\mathrm{RuHCl}(\mathrm{CO})\left(\mathbf{P P h}_{3}\right)_{2}(\mathrm{~L})\right]\left(\mathrm{L}=\mathbf{P P h}_{3}, \mathbf{P y}\right.$, 3,5-dimethylpyrazole, 2,1,3-benzoselenadiazole $)^{a}$

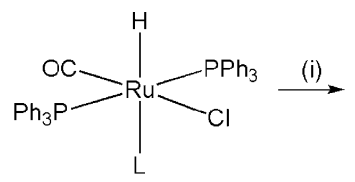

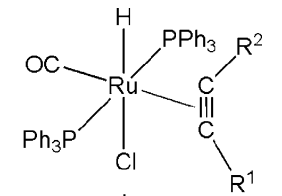

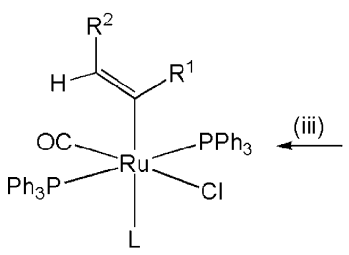

(ii)<smiles>[R]/C=C(/[R])[R](P)(Cl)[PH2](=O)[O-]</smiles>

${ }^{a}$ Legend: (i) $-\mathrm{L},+\mathrm{R}^{1} \mathrm{C} \equiv \mathrm{CR} ;^{2}$ (ii) alkyne insertion; (iii) $+\mathrm{L}$ $\left(\mathrm{L} \neq \mathrm{PPh}_{3}\right)$.

Thiocarbonyl ligands display an enhanced propensity for entering into migratory insertion reactions, compared with the case for carbonyl ligands. In this respect migratory insertion reactions involving thiocarbonyls and hydride, ${ }^{3}$ aryl, ${ }^{4}$ silyl, ${ }^{5}$ boryl, ${ }^{6 \mathrm{a}}$ and borane ${ }^{6 \mathrm{~b}}$ ligands have been demonstrated previously. While parallels with aryl-carbonyl coupling are not surprising, the migration reactions involving hydride, silyl, and boryl 
Chart 1. Thioacyl and Metallathiirene Canonical Forms

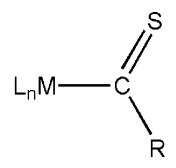

A

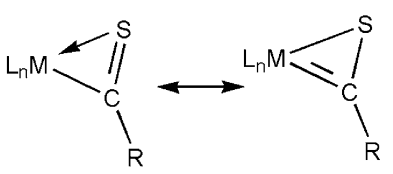

C ligands are remarkable, given that these are not generally observed for carbonyl ligands. Furthermore, metallacyclic thioacyls are implicitly or directly observed in the coupling of alkynes with thiocarbonyl ligands en route to metallacyclobutenethiones, metallabenzenes, or cyclopentadienethione complexes. ${ }^{7}$ This facility may be traced to the $\pi$-acceptor orbitals of free CS being of lower energy than those for CO. However, given that the majority of these observed reactions have involved divalent ("soft") ruthenium or osmium complexes that convert to bidentate thioacyls (metallathiirenes, $\mathbf{C}$; Chart 1$),{ }^{9}$ the strength of the resulting $\mathrm{M}-\mathrm{S}(\mathrm{M}=\mathrm{Ru}$, Os $)$ bond presumably contributes a thermodynamic impetus for the process.

Migratory insertion reactions involving alkenyl and thiocarbonyl ligands remain rare, ${ }^{7 b, f, 9}$ primarily due to the lack of suitable substrates bearing both these ligands. The osmium complex $\left[\mathrm{Os}(\mathrm{CPh}=\mathrm{CHPh}) \mathrm{Cl}(\mathrm{CS})\left(\mathrm{PPh}_{3}\right)_{2}\right]$ results from the addition of hydrogen chloride to the zerovalent tolane complex $\left[\mathrm{Os}(\mathrm{CS})(\mathrm{PhC} \equiv \mathrm{CPh})\left(\mathrm{PPh}_{3}\right)_{2}\right]$ and undergoes $\mathrm{CO}$-promoted migratory insertion. ${ }^{7 \mathrm{~b}}$ However, the synthesis of the precursor alkyne complex is not general, e.g., the reaction of $[\mathrm{Os}(\mathrm{CO})$ $\left.(\mathrm{CS})\left(\mathrm{PPh}_{3}\right)_{3}\right]$ with propyne proceeds via oxidative addition to provide, inter alia, $\left[\mathrm{OsH}(\mathrm{C} \equiv \mathrm{CMe})(\mathrm{CO})(\mathrm{CS})\left(\mathrm{PPh}_{3}\right)_{2}\right]$, and while the alkynyl ligand of this complex does not itself undergo migratory insertion, addition of $\mathrm{HCl}$ provides the thioacyl derivative $\left[\mathrm{Os}\left(\eta^{2}-\mathrm{SCCH}=\mathrm{CHMe}\right) \mathrm{Cl}(\mathrm{CO})\left(\mathrm{PPh}_{3}\right)_{2}\right]$ via the presumed intermediacy of vinylidene- and alkenyl-thiocarbonyl complexes (Scheme 2). ${ }^{7 \mathrm{f}}$

(2) (a) Bedford, R. B.; Hill, A. F.; Jones, C.; White, A. J. P.; Williams, D. J.; Wilton-Ely, J. D. E. T. Organometallics 1998, 17, 4744. (b) Hill, A. F.; Jones, C.; White, A. J. P.; Williams, D. J.; Wilton-Ely, J. D. E. T. J. Chem. Soc., Dalton Trans. 1998, 1419. (c) Hill, A. F.; Jones, C.; White, A J. P.; Williams, D. J.; Wilton-Ely, J. D. E. T. Chem. Commun. 1998, 367. (d) Bedford, R. B.; Hill, A. F.; Jones, C.; White, A. J. P.; Williams, D. J.; Wilton-Ely, J. D. E. T. J. Chem. Soc., Dalton Trans. 1997, 1113. (e) Bedford, R. B.; Hill, A. F.; Jones, C.; White, A. J. P.; Wilton-Ely, J. D. E. T. J. Chem. Soc., Dalton Trans. 1997, 139. (f) Bedford, R. B.; Hill, A. F.; Jones, C.; White, A. J. P.; Williams, D. J.; Wilton-Ely, J. D. E. T. Chem. Commun. 1997, 179. (g) Bedford, R. B.; Hibbs, D. E.; Hill, A. F.; Hursthouse, M. B.; Malik, K. M. A.; Jones, C. Chem. Commun. 1996, 1895. (h) Bedford, R. B.; Hill, A. F.; Jones, C. Angew. Chem., Int. Ed. Engl. 1996, 35, 547.

(3) (a) Collins, T. J.; Roper, W. R. J. Organomet. Chem. 1978, 159, 73.

(b) Roper, W. R.; Town, K. G. J. Chem. Soc., Chem. Commun. 1977, 781. (c) Collins, T. J.; Roper, W. R. J. Chem. Soc., Chem. Commun. 1976, 1044.

(4) (a) Clark, G. R.; Collins, T. J.; Marsden, K.; Roper, W. R. J. Organomet. Chem. 1978, 157, C23. (b) Clark, G. R.; Collins, T. J.; Marsden, K.; Roper, W. R. J. Organomet. Chem. 1983, 259, 215.

(5) Rickard, C. E. F.; Roper, W. R.; Salter, D. M.; Wright, L. J. Organometallics 1992, 11, 3931.

(6) (a) Irvine, G. J.; Lesley, M. J. G.; Marder, T. B.; Norman, N. C.; Rice, C. R.; Robins, E. G.; Roper, W. R.; Whittell, G. R.; Wright, L. J. Chem. Rev. 1998, 98, 2685. (b) Crossley, I. R.; Hill, A. F.; Willis, A. C. Organometallics 2007, 26, 3891.

(7) (a) Clark, G. R.; Lu, G.-L.; Roper, W. R.; Wright, L. J. Organometallics 2007, 26, 2167. (b) Elliott, G. P.; Roper, W. R. J. Organomet. Chem. 1983, 250, C5. (c) Elliott, G. P.; Roper, W. R.; Waters, J. M. J. Chem. Soc., Chem. Commun. 1982, 811. (d) Clark, G. R.; Johns, P. M.; Roper, W. R.; Wright, L. J. Organometallics 2006, 25, 1771. (e) Lu, G.-L.; Roper, W. R.; Wright, L. J.; Clark, G. R. J. Organomet. Chem. 2005, 690, 972. (f) Rickard, C. E. F.; Roper, W. R.; Woodgate, S. D.; Wright, L. J. J. Organomet. Chem. 2001, 623, 109. (g) Hill, A. F.; Schultz, M.; Willis, A. C. Organometallics 2005, 24, 2027.

(8) The exception, to date, involves thioformyl complexes, ${ }^{3}$ all of which appear to involve mondentate coordination.

(9) Cannadine, J.; Hector, A.; Hill, A. F. Organometallics 1992, 11, 2323.
Scheme 2. Osmium Alkenyl-Thiocarbonyl Migratory Insertion Reactions $\left(\mathbf{L}=\mathbf{P P h}_{3}\right)^{a, 7 b, f}$

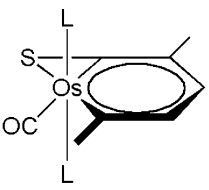<smiles>O=C1C(=S)C(Cl)(I)C(=O)C1(I)c1ccccc1</smiles>

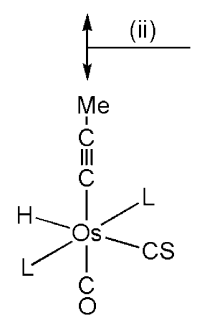

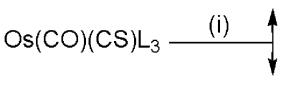<smiles>IC(I)(OC(=Cc1ccccc1)Pc1ccccc1)c1ccccc1</smiles>

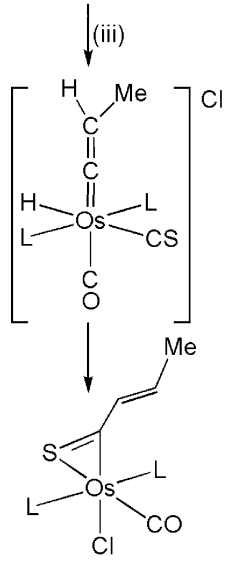

(iii)<smiles>S=P(Cl)(Cl)C(=Cc1ccccc1)c1ccccc1</smiles>

(iv)

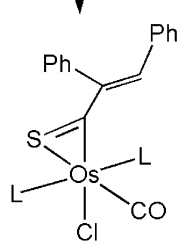

${ }^{a}$ Legend: (i) $\mathrm{PhC} \equiv \mathrm{CPh},-\mathrm{CO}$; (ii) $\mathrm{HC} \equiv \mathrm{CMe}$; (iii) $\mathrm{HCl}$; (iv) $\mathrm{CO}$.

Herein, we report synthetic routes to a range of fivecoordinate electronically unsaturated alkenyl-thiocarbonyl complexes of ruthenium(II), $\left[\mathrm{Ru}\left(\mathrm{CR}^{1}=\mathrm{CHR}^{2}\right) \mathrm{Cl}(\mathrm{CS})\left(\mathrm{PPh}_{3}\right)_{2}\right]$. We have previously reported briefly on the use of these complexes in other studies 9,10 and now provide full details of their preparation and ligand addition-substitution chemistry. These species are well-disposed for studying the migratory insertion reactions of $\sigma$-alkenyl and thiocarbonyl ligands. The potential of these complexes for the preparation of polymetallic ensembles using 1,4-diethynylbenzene and a bridging dicarboxylate is also demonstrated.

\section{Results and Discussion}

The complex $\left[\mathrm{RuHCl}(\mathrm{CS})\left(\mathrm{PPh}_{3}\right)_{3}\right]$ is available via thermal decarboxylation of the bidentate formato complex $\left[\mathrm{RuCl}\left(\kappa^{2}-\right.\right.$ $\left.\left.\mathrm{O}_{2} \mathrm{CH}\right)(\mathrm{CS})\left(\mathrm{PPh}_{3}\right)_{2}\right]$, which is in turn obtained from the reaction of $\left[\mathrm{RuCl}_{2}\left(\mathrm{OH}_{2}\right)(\mathrm{CS})\left(\mathrm{PPh}_{3}\right)_{2}\right]$ with sodium formate. ${ }^{11}$ Heating a suspension of $\left[\mathrm{RuCl}\left(\mathrm{O}_{2} \mathrm{CH}\right)(\mathrm{CS})\left(\mathrm{PPh}_{3}\right)_{2}\right]$ and diphenylacetylene in ethanol under reflux leads to the formation of a bright orange suspension of a complex formulated as $[\mathrm{Ru}(\mathrm{CPh}=\mathrm{CHPh}) \mathrm{Cl}$ $\left.(\mathrm{CS})\left(\mathrm{PPh}_{3}\right)_{2}\right](\mathbf{1})$. The product shows virtually no change in the thiocarbonyl infrared absorption observed at $1290 \mathrm{~cm}^{-1}(1292$ $\mathrm{cm}^{-1}$ in the starting complex). However, the disappearance of infrared bands attributed to the bidentate formato ligand (1545, 1358 , and $810 \mathrm{~cm}^{-1}$ ) is conspicuous. Bands at 1597,1587 , and $1570 \mathrm{~cm}^{-1}$ appear in the spectrum of the product and are

(10) Wilton-Ely, J. D. E. T.; Honarkhah, S. J.; Wang, M.; Tocher, D. A.; Slawin, A. M. Z. Dalton Trans. 2005, 1930.

(11) (a) Brothers, P. J.; Headford, C. E. L.; Roper, W. R. J. Organomet. Chem. 1980, 195, C29. (b) Brothers, P. J.; Roper, W. R. J. Organomet. Chem. 1983, 258, 73. 


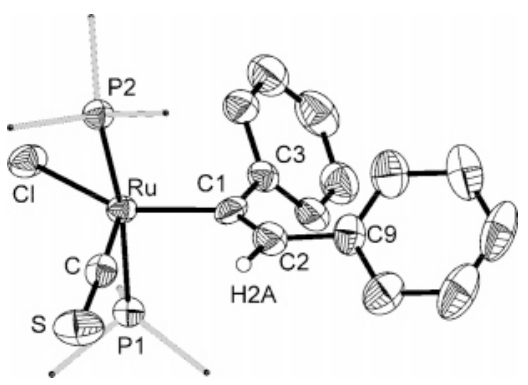

Figure 1. Molecular structure of $\mathbf{1}$ (phosphine phenyl groups and phenyl hydrogen atoms omitted, 50\% displacement ellipsoids). Selected bond lengths $(\AA)$ and angles (deg): $\mathrm{Ru}-\mathrm{C}=1.749(7)$, $\mathrm{Ru}-\mathrm{Cl}=2.4300(17), \mathrm{Ru}-\mathrm{P}(1)=2.4076(17), \mathrm{Ru}-\mathrm{P}(2)=2.4240-$ (17), $\mathrm{Ru}-\mathrm{C}(1)=2.045(6), \mathrm{C}-\mathrm{S}=1.574(7), \mathrm{C}(1)-\mathrm{C}(2)=1.351-$ (8); $\mathrm{P}(1)-\mathrm{Ru}-\mathrm{P}(2)=171.45(6), \mathrm{Ru}-\mathrm{C}-\mathrm{S}=176.7(5), \mathrm{C}(2)-$ $\mathrm{C}(1)-\mathrm{C}(3)=124.1(6), \mathrm{Ru}-\mathrm{C}(1)-\mathrm{C}(2)=132.5(5), \mathrm{Ru}-\mathrm{C}(1)-$ $\mathrm{C}(3)=103.1(4)$.

characteristic of the stilbenyl group in this and subsequent derivatives. The ${ }^{1} \mathrm{H}$ NMR data for the complex were of limited use for characterization, and so the corresponding di-p-tolyl derivative was also prepared by an analogous procedure. Infrared data were similar and the ${ }^{1} \mathrm{H}$ NMR data somewhat more informative: the vinylic proton is observed to resonate at 5.58 ppm in the ${ }^{1} \mathrm{H}$ NMR spectrum of the complex, and this resonance shows poorly resolved weak coupling to two chemically equivalent phosphorus nuclei, suggesting a trans disposition of the two phosphine ligands. In addition, two methyl resonances and two $(\mathrm{AB})_{2}$ patterns for the para-disubstituted $\mathrm{C}_{6} \mathrm{H}_{4}$ groups indicate the chemical inequivalence of the two tolyl substituents. The carbonyl analogue of the stilbenyl complex $[\mathrm{Ru}(\mathrm{CPh}=$ $\mathrm{CHPh}) \mathrm{Cl}(\mathrm{CO})\left(\mathrm{PPh}_{3}\right)_{2}$ ] has been prepared previously ${ }^{1 \mathrm{a}}$ from the reaction of $\left[\mathrm{RuHCl}(\mathrm{CO})\left(\mathrm{PPh}_{3}\right)_{3}\right]$ with diphenylacetylene and structurally characterized. The formulation of $[\mathrm{Ru}(\mathrm{CPh}=\mathrm{CHPh})-$ $\left.\mathrm{Cl}(\mathrm{CS})\left(\mathrm{PPh}_{3}\right)_{2}\right]$ (1) was subsequently confirmed by a crystallographic study, the results of which are summarized in Figure 1 and discussed below. Table 1 also summarizes relevant dimensions for the complex $\left[\mathrm{RuCl}(\mathrm{CPh}=\mathrm{CHPh})(\mathrm{CO})\left(\mathrm{PPh}_{3}\right)_{2}\right]$ for comparison, and these will be discussed below.

The reaction sequence most likely proceeds via thermal decarboxylation of the formato ligand to produce the coordinatively unsaturated (or solvated) hydrido complex "RuHCl$(\mathrm{CS})\left(\mathrm{PPh}_{3}\right)_{2}$ ", which then undergoes hydroruthenation of the alkyne (Scheme 3). Thermolysis of $\left[\mathrm{RuCl}\left(\kappa^{2}-\mathrm{O}_{2} \mathrm{CH}\right)(\mathrm{CS})\right.$ $\left.\left(\mathrm{PPh}_{3}\right)_{2}\right]$ in the presence of triphenylphosphine is known to produce the tris(phosphine) complex $\left[\operatorname{RuHCl}(\mathrm{CS})\left(\mathrm{PPh}_{3}\right)_{3}\right] .{ }^{11}$ The trans influence of the hydride ligand, combined with steric pressures associated with the mer- $\mathrm{Ru}\left(\mathrm{PPh}_{3}\right)_{3}$ geometry in this complex, labilizes the unique phosphine completely ( ${ }^{31} \mathrm{P}$ NMR) to yield the 16-electron hydrido species in solution. Accordingly, $\left[\mathrm{RuHCl}(\mathrm{CS})\left(\mathrm{PPh}_{3}\right)_{3}\right]$ reacts with diphenylacetylene when heated in tetrahydrofuran under reflux $(10 \mathrm{~min})$ to provide the same complex, $\left[\mathrm{Ru}(\mathrm{CPh}=\mathrm{CHPh}) \mathrm{Cl}(\mathrm{CS})\left(\mathrm{PPh}_{3}\right)_{2}\right](\mathbf{1})$; however, the formate decarboxylation route is practically more expedient. The reaction of $\left[\mathrm{RuHCl}(\mathrm{CS})\left(\mathrm{PPh}_{3}\right)_{3}\right]$ with alkynes is, however, more generally applicable, allowing extension to terminal alkynes. Thus, a solution of $\left[\mathrm{RuHCl}(\mathrm{CS})\left(\mathrm{PPh}_{3}\right)_{3}\right]$ reacts with ethynylbenzene in dichloromethane at room temperature to provide the trans- $\beta$-styryl derivative $\left[\mathrm{Ru}(\mathrm{CH}=\mathrm{CHPh}) \mathrm{Cl}(\mathrm{CS})\left(\mathrm{PPh}_{3}\right)_{2}\right]$ (2) (Scheme 3). The stereochemistry of hydroruthenation follows from the observation of a vinylic $\mathrm{AB}$ system in the ${ }^{1} \mathrm{H}$ NMR spectrum of the product $\left(\delta_{\mathrm{H}} 8.65,6.15 \mathrm{ppm} ; J_{\mathrm{AB}}=14.1 \mathrm{~Hz}\right)$. The low-field resonance shows a further coupling of $2.9 \mathrm{~Hz}$ to two chemically equivalent phosphorus nuclei, consistent with this proton being $\alpha$ to the $\left(\mathrm{Ph}_{3} \mathrm{P}\right)_{2} \mathrm{Ru}$ unit. The parent ethenyl complex $\left[\mathrm{Ru}\left(\mathrm{CH}=\mathrm{CH}_{2}\right) \mathrm{Cl}(\mathrm{CS})\left(\mathrm{PPh}_{3}\right)_{2}\right](3)$ was similarly prepared from the rapid reaction of a solution of $[\mathrm{RuHCl}(\mathrm{CS})$ $\left.\left(\mathrm{PPh}_{3}\right)_{3}\right]$ with ethyne. While the resonance due to $\mathrm{H}_{\alpha}$ is obscured by phosphine resonances, the geminal $=\mathrm{CH}_{\beta} \mathrm{H}_{\beta^{\prime}}$ group (see Scheme 3 for notation) gives rise to two clear multiplets centered at 4.68 and $5.08 \mathrm{ppm}$. The resonance to higher field $\left(\mathrm{H}_{\beta}, J_{\mathrm{H}_{\alpha} \mathrm{H}_{\beta}}\right.$ $=14.2 \mathrm{~Hz}, J_{\mathrm{H}_{\beta} \mathrm{H}_{\beta^{\prime}}}=1.7 \mathrm{~Hz}$ ) also shows broadening due to coupling to phosphorus. Reaction between 1,4-diphenylbutadiyne and the hydride starting material provides the enynyl complex $\left[\mathrm{Ru}\{\mathrm{C}(\mathrm{C} \equiv \mathrm{CPh})=\mathrm{CHPh}\} \mathrm{Cl}(\mathrm{CS})\left(\mathrm{PPh}_{3}\right)_{2}\right]$ (4) by analogy with the previously reported carbonyl analogues $[\mathrm{Ru}\{\mathrm{C}(\mathrm{C} \equiv$ $\left.\mathrm{CR})=\mathrm{CHR}\} \mathrm{Cl}(\mathrm{CO})\left(\mathrm{PPh}_{3}\right)_{2}\right]\left(\mathrm{R}=\mathrm{C}_{6} \mathrm{H}_{5}, \mathrm{C}_{6} \mathrm{H}_{4} \mathrm{Me},{ }^{t} \mathrm{Bu},{ }^{n} \mathrm{Bu}\right.$, $\left.\mathrm{CMe}_{2} \mathrm{OH}, \mathrm{SiMe}_{3}\right){ }^{12}$ The molecular structure of this complex was also confirmed by a crystallographic study (Figure 2).

The single alkenyl proton gives rise to a triplet resonance at $\delta 5.50\left(J_{\mathrm{HP}}=1.7 \mathrm{~Hz}\right) \mathrm{ppm}$ in the ${ }^{1} \mathrm{H}$ NMR spectrum. The presence of an uncoordinated $\mathrm{C} \equiv \mathrm{CPh}$ triple bond is suggested by a weak absorption at $2123 \mathrm{~cm}^{-1}$ in the solid-state infrared spectrum (Nujol).

In contrast to the above results, the rapid reaction of [ $\mathrm{RuHCl}-$ $(\mathrm{CS})\left(\mathrm{PPh}_{3}\right)_{3}$ ] with dimethyl acetylenedicarboxylate (DMAD) rapidly provides the pale yellow complex $\left[\mathrm{Ru}\left\{\mathrm{C}\left(\mathrm{CO}_{2} \mathrm{Me}\right)=\right.\right.$ $\left.\left.\mathrm{CHCO}_{2} \mathrm{Me}\right\} \mathrm{Cl}(\mathrm{CS})\left(\mathrm{PPh}_{3}\right)_{2}\right]$ (5). Five-coordinate $\sigma$-alkenyl complexes of the form $\left[\mathrm{Ru}\left(\mathrm{CR}^{1}=\mathrm{CHR}^{2}\right) \mathrm{Cl}(\mathrm{CA})\left(\mathrm{PPh}_{3}\right)_{2}\right](\mathrm{A}=\mathrm{O}$, $\mathrm{S})$ are typically brightly colored, and the pale color of this derivative suggests that the $\sigma$-alkenyl ligand is in fact metallacyclic in nature, with one of the methoxycarbonyl groups acting as a sixth ligand to ruthenium, resulting in octahedral coordination. Such a five-membered metallacycle is also formed in the reaction of other ruthenium hydrido complexes with DMAD. ${ }^{1,13,14}$ It is noteworthy that the formation of this type of ligand ultimately requires the less common trans hydroruthenation of the alkyne (cis- $\beta$ geometry), concerted insertion typically providing the trans- $\beta$ stereochemistry. The possibility of eventual chelation presumably provides the driving force for the observed outcome, and a discussion of possible intramolecular rearrangements of this type of ligand has been provided by Stone. ${ }^{14}$ It should be noted that an equilibrium between $\sigma$-alkenyl and $\sigma-\pi$-alkenyl coordination would also allow for cis - trans isomerism of the vinyl ligand (Chart 2).

Addition of Ligands. A coordinatively saturated alkenyl species was prepared by the reaction of $\left[\mathrm{Ru}\left(\mathrm{CH}=\mathrm{CH}_{2}\right) \mathrm{Cl}(\mathrm{CS})\right.$ $\left(\mathrm{PPh}_{3}\right)_{2}$ ] (3) with 2,1,3-benzoselenadiazole (BSD), which provides $\left[\mathrm{Ru}\left(\mathrm{CH}=\mathrm{CH}_{2}\right) \mathrm{Cl}(\mathrm{CS})(\mathrm{BSD})\left(\mathrm{PPh}_{3}\right)_{2}\right](\mathbf{6})$. As has been previously noted, ${ }^{15}$ the BTD ligand has no reliably characteristic spectroscopic features, due to the aromatic protons being obscured by those of the phosphines in the ${ }^{1} \mathrm{H}$ NMR spectrum. Furthermore, the infrared absorptions for this ligand are typically weak. Nevertheless, the ligand serves as a dramatic visible chromophore, imparting intense colors to the derived complexes. Thus, coordination of BSD to the deep red precursor provides a bright yellow adduct. As with the precursor, clear resonances

(12) (a) Hill, A. F.; Melling, R. P. J. Organomet. Chem. 1990, 396, C22. (b) Hill, A. F.; Melling, R. P.; Thompsett, A. R. J. Organomet. Chem. 1991, 402, C8. (c) Wakatsuki, Y.; Yamazaki, H.; Kumgawa, N.; Satoh, T.; Satoh, J. J. Am. Chem. Soc. 1991, 113, 9604. (d) Alcock, N. W.; Hill, A. R.; Melling, R. P.; Thompsett, A. R. Organometallics 1993, 12, 641. (e) Hill, A. F.; Harris, M. C. J.; Melling, R. P. Polyhedron 1992, 11, 781. (f) Xia, H. P.; Yeung, R. C. Y.; Jia, G. Organometallics 1998, 17, 4762.

(13) Vessey, J. D.; Mawby, R. J. J. Chem. Soc., Dalton Trans. 1993, 51

(14) Blackmore, T.; Bruce, M. I.; Stone, F. G. A. J. Chem. Soc., Dalton Trans. 1974, 106.

(15) (a) Harris, M. C. J.; Hill, A. F. Organometallics 1991, 10, 3903 (b) Harris, M. C. J.; Hill, A. F. J. Organomet. Chem. 1992, 438, 209. (c) Herberhold, M.; Hill, A. F. J. Organomet. Chem. 1989, 377, 151. (d) Alcock, N. W.; Hill, A. F.; Roe, M. S. J. Chem. Soc., Dalton Trans. 1990, 1737. 
Table 1. Selected Geometrical Data for Ruthenium(II) Alkenyl Complexes ${ }^{a}$

\begin{tabular}{|c|c|c|c|}
\hline complex & $\mathrm{Ru}-\mathrm{C}_{\alpha}$ & $\mathrm{C}_{\alpha}-\mathbf{C}_{\beta}$ & $\mathrm{Ru}-\mathrm{C}_{\alpha}-\mathrm{C}_{\beta}$ \\
\hline$\left[\mathrm{Ru}(\mathrm{CH}=\mathrm{CHPh})\left(\kappa^{2}-\mathrm{O}_{2} \mathrm{CMe}\right)(\mathrm{CO}) \mathrm{L}_{2}\right]^{1 \mathrm{cc}}$ & $2.030(15)$ & $1.294(14)$ & $125.6(8)$ \\
\hline$\left[\mathrm{Ru}(\mathrm{CPh}=\mathrm{CHPh}) \mathrm{Cl}(\mathrm{CO}) \mathrm{L}_{2}\right]^{1 \mathrm{a}}$ & $2.03(1)$ & $1.37(2)$ & $130.7(9)$ \\
\hline$\left[\mathrm{Ru}(\mathrm{CH}=\mathrm{CHPh})\left(\kappa^{2}-\mathrm{O}_{2} \mathrm{CH}\right)(\mathrm{CO}) \mathrm{L}_{2}\right]^{\mathrm{lh}}$ & $2.036(8)$ & $1.35(1)$ & $124.4(7)$ \\
\hline$\left[\mathrm{Ru}(\mathrm{CH}=\mathrm{CHPh})\left(\mathrm{C}_{13} \mathrm{H}_{9} \mathrm{ClNO}\right)(\mathrm{CO}) \mathrm{L}_{2}\right]^{26}$ & $2.0380(18)$ & $1.338(3)$ & $134.89(14)$ \\
\hline$\left[\mathrm{Ru}(\mathrm{CR}=\mathrm{CHR})\left(\mathrm{O}_{2} \mathrm{COH}\right)(\mathrm{CO}) \mathrm{L}_{2}\right]^{1 \mathrm{~b}}$ & $2.044(9)$ & $1.33(2)$ & $128.9(7)$ \\
\hline$\left[\mathrm{Ru}(\mathrm{CPh}=\mathrm{CHPh}) \mathrm{Cl}(\mathrm{CS}) \mathrm{L}_{2}\right](\mathbf{1})$ & $2.045(6)$ & $1.351(8)$ & $132.5(5)$ \\
\hline$\left[\mathrm{Ru}\left(\mathrm{CH}=\mathrm{CHC}_{3} \mathrm{H}_{7}\right) \mathrm{Cl}(\mathrm{CO})\left(\mathrm{Me}_{2} \mathrm{Hpz}\right) \mathrm{L}_{2}\right]^{27}$ & $2.05(1)$ & $1.32(2)$ & 134(1) \\
\hline$\left[\mathrm{Ru}\left(\mathrm{CH}=\mathrm{CHC}_{6} \mathrm{H}_{4} \mathrm{Me}-4\right)\left(\mathrm{C}_{4} \mathrm{H}_{5} \mathrm{~N}_{2} \mathrm{~S}\right)(\mathrm{CO}) \mathrm{L}_{2}\right]^{10}$ & $2.058(6)$ & $1.319(7)$ & $128.7(5)$ \\
\hline$\left[\mathrm{Ru}\left(\mathrm{CH}=\mathrm{CH}^{\mathrm{t}} \mathrm{Bu}\right) \mathrm{Cl}(\mathrm{CO})\left(\mathrm{HpzMe}_{2}\right) \mathrm{L}_{2}\right]^{1 \mathrm{~b}}$ & $2.063(7)$ & $1.33(1)$ & $133.4(6)$ \\
\hline$\left[\mathrm{Ru}\left(\mathrm{CH}=\mathrm{CHC}_{6} \mathrm{H}_{4} \mathrm{Me}-4\right)\left(\mathrm{C}_{5} \mathrm{H}_{4} \mathrm{NO}\right)(\mathrm{CO}) \mathrm{L}_{2}\right]^{28}$ & $2.067(3)$ & $1.325(5)$ & $125.2(4)$ \\
\hline$\left[\mathrm{Ru}\left(\mathrm{CH}=\mathrm{CH}^{\mathrm{H}} \mathrm{Bu}\right)\left\{\mathrm{HN}=\mathrm{C}(\mathrm{Me}) \mathrm{pzMe}_{2}\right\}(\mathrm{CO}) \mathrm{L}_{2}\right]^{+29}$ & $2.067(8)$ & $1.32(1)$ & $132.9(7)$ \\
\hline$\left[\mathrm{Ru}\left(\mathrm{CH}=\mathrm{CH}_{2}\right)\left\{\kappa^{2}-\mathrm{H}_{2} \mathrm{~B}(\mathrm{pz})_{2}\right\}(\mathrm{CO}) \mathrm{L}_{2}\right]^{30}$ & $2.080(7)$ & $1.345(11)$ & $131.1(6)$ \\
\hline$\left[\mathrm{Ru}\left(\mathrm{CH}=\mathrm{CH}_{2}\right)\left(\mathrm{C}_{9} \mathrm{H}_{12} \mathrm{NS}\right)(\mathrm{CO}) \mathrm{L}_{2}\right]^{28}$ & $2.083(2)$ & $1.330(3)$ & 131.31(19) \\
\hline$\left[\mathrm{Ru}\left(\mathrm{CH}=\mathrm{CH}_{2}\right)(\mathrm{CO})\left([9] \mathrm{aneS}_{3}\right) \mathrm{L}\right]^{+31}$ & 2.097(5) & $1.292(7)$ & $130.3(5)$ \\
\hline$\left[\mathrm{Ru}(\mathrm{CPh}=\mathrm{CHPh})\left(\mathrm{C}_{4} \mathrm{H}_{5} \mathrm{~N}_{2} \mathrm{~S}\right)(\mathrm{CS}) \mathrm{L}_{2}\right]^{26}$ & $2.102(2)$ & $1.337(3)$ & $126.64(17)$ \\
\hline$\left[\mathrm{Ru}\left\{\mathrm{C}\left(\mathrm{O}^{\mathrm{i} P r}\right)=\mathrm{CHPh}\right\}\left(\eta^{5}-\mathrm{C}_{5} \mathrm{H}_{5}\right)(\mathrm{CO}) \mathrm{L}\right]^{32}$ & $2.103(6)$ & $1.335(8)$ & $122.7(5)$ \\
\hline$\left[\mathrm{Ru}(\mathrm{CR}=\mathrm{CHR})(\mathrm{CO})(\mathrm{NCMe})_{2} \mathrm{~L}_{2}\right]^{+33}$ & $2.12(5)$ & $1.41(7)$ & $122(4)$ \\
\hline
\end{tabular}

${ }^{a} \mathrm{~L}=\mathrm{PPh}_{3} ; \mathrm{R}=\mathrm{CO}_{2} \mathrm{Me}$. Distances are given in $\AA$ and angles in deg.

\section{Scheme $3^{a}$}

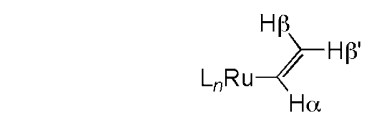<smiles>OCO[Te](Cl)(Cl)(Cl)I</smiles><smiles></smiles><smiles>[R]C=C([R1])[R]([Si])(Cl)Cl</smiles>
(ii) $\downarrow$<smiles>[3H][R]([SiH3])([SiH3])Cl</smiles>

$$
\begin{array}{lr}
\mathrm{R}^{1}=\mathrm{R}^{2}=P h & \mathbf{1} \\
\mathrm{R}^{1}=\mathrm{H}, \mathrm{R}^{2}=P h & \mathbf{2} \\
\mathrm{R}^{1}=\mathrm{R}^{2}=\mathrm{H} & \mathbf{3} \\
\mathrm{R}^{1}=\mathrm{C} \equiv \mathrm{CPh}, \mathrm{R}^{2}=\mathrm{Ph} \mathbf{4}
\end{array}
$$

(iii)

${ }^{a} \mathrm{~L}=\mathrm{PPh}_{3}$. Legend: (i) $\mathrm{PhC} \equiv \mathrm{CPh}$; (ii) $\mathrm{PPh}_{3}$, heat; ${ }^{11 \mathrm{~b}}$ (iii) $\mathrm{R}^{1} \mathrm{C} \equiv \mathrm{CR}$. ${ }^{2}$

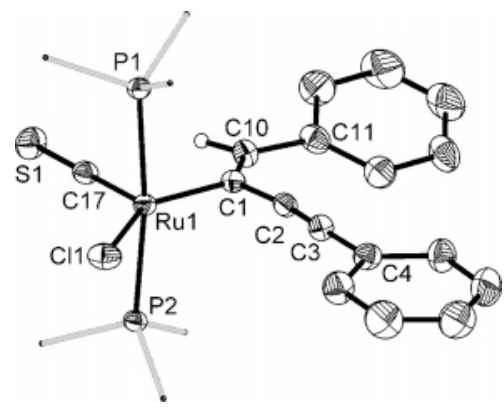

Figure 2. Molecular structure of $\mathbf{4}$ (phosphine phenyl groups and phenyl hydrogen atoms omitted, 50\% displacement ellipsoids). Selected bond lengths $(\AA)$ and angles $(\mathrm{deg}): \mathrm{Ru}(1)-\mathrm{C}(17)=1.753$ (4), $\mathrm{Ru}(1)-\mathrm{Cl}(1)=2.4313(10), \mathrm{Ru}(1)-\mathrm{P}(1)=2.4051(10), \mathrm{Ru}-$ $(1)-\mathrm{P}(2)=2.3904(10), \mathrm{Ru}(1)-\mathrm{C}(1)=2.027(4), \mathrm{C}(17)-\mathrm{S}(1)=$ $1.582(4), \mathrm{C}(1)-\mathrm{C}(10)=1.352(6), \mathrm{C}(2)-\mathrm{C}(3)=1.211(6) ; \mathrm{P}(1)-$ $\mathrm{Ru}(1)-\mathrm{P}(2)=173.20(4), \mathrm{Ru}(1)-\mathrm{C}(17)-\mathrm{S}(1)=179.2(3), \mathrm{C}(10)-$ $\mathrm{C}(1)-\mathrm{C}(2)=127.2(4), \mathrm{Ru}(1)-\mathrm{C}(1)-\mathrm{C}(10)=135.4(3), \mathrm{Ru}(1)-$ $\mathrm{C}(1)-\mathrm{C}(2)=97.3(2), \mathrm{C}(1)-\mathrm{C}(2)-\mathrm{C}(3)=170.0(4)$.

due to the $\mathrm{CH}_{\beta} \mathrm{H}_{\beta^{\prime}}$ group are apparent in the ${ }^{1} \mathrm{H}$ NMR spectrum; however, as a result of coordination of a strong donor ligand trans to the alkenyl ligand, the resonance due to $\mathrm{H}_{\alpha}$ becomes shifted to lower field of the phosphine resonances $(8.18 \mathrm{ppm})$.

The related carbonyl complexes [ $\mathrm{Ru}($ alkenyl) $\mathrm{Cl}(\mathrm{CO})(\mathrm{BSD})-$ $\left.\left(\mathrm{PPh}_{3}\right)_{2}\right]^{15}$ may be prepared from the hydrido complex [RuHCl-
Chart 2. Alternative Rationales for Cis to Trans Isomerism of $\beta$-Carboalkoxyvinyl Ligands $\left(\mathrm{R}=\mathrm{CO}_{2} \mathrm{Me}\right)$

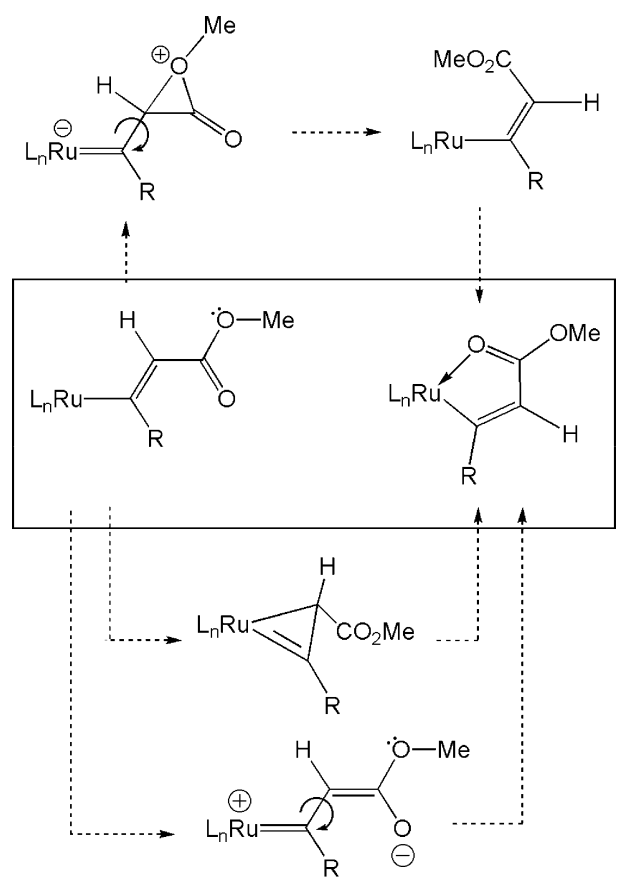

$\left.(\mathrm{CO})(\mathrm{BSD})\left(\mathrm{PPh}_{3}\right)_{2}\right],{ }^{15 \mathrm{~d}}$ which readily hydroruthenates alkynes. In some cases these hydroruthenation reactions proceed more cleanly than those of the tris(phosphine) complex $[\mathrm{RuHCl}(\mathrm{CO})$ $\left.\left(\mathrm{PPh}_{3}\right)_{3}\right]$, avoiding contamination by $[\mathrm{Ru}($ alkenyl $) \mathrm{Cl}(\mathrm{CO})$ $\left.\left(\mathrm{PPh}_{3}\right)_{3}\right]$. Accordingly, the thiocarbonyl analogue $[\mathrm{RuHCl}(\mathrm{CS})-$ $\left.(\mathrm{BSD})\left(\mathrm{PPh}_{3}\right)_{2}\right](7)$ was prepared by the reaction of $[\mathrm{RuHCl}(\mathrm{CS})$ $\left(\mathrm{PPh}_{3}\right)_{3}$ ] with BSD in refluxing tetrahydrofuran. The geometry at ruthenium is assumed to be the same as that established for $\left[\mathrm{RuHCl}(\mathrm{CO})(\mathrm{BSD})\left(\mathrm{PPh}_{3}\right)_{2}\right],{ }^{15 \mathrm{~d}}$ i.e., that shown in Scheme 4, involving trans phosphines and the coordination of the hydride ligand cis to the $\mathrm{BSD}$. The reaction of $[\mathrm{RuHCl}(\mathrm{CS})(\mathrm{BSD})$ $\left(\mathrm{PPh}_{3}\right)_{2}$ ] (7) with ethyne ensues at room temperature to provide $\left[\mathrm{Ru}\left(\mathrm{CH}=\mathrm{CH}_{2}\right) \mathrm{Cl}(\mathrm{CS})(\mathrm{BSD})\left(\mathrm{PPh}_{3}\right)_{2}\right](\mathbf{6})$ in high yield and is probably accompanied by a change in geometry such that the BSD ligand in the product resides trans to the $\sigma$-alkenyl ligand.

The osmium complex $\left[\mathrm{Os}\left(\mathrm{C}_{6} \mathrm{H}_{4} \mathrm{Me}-4\right) \mathrm{Cl}(\mathrm{CS})\left(\mathrm{PPh}_{3}\right)_{2}\right]^{4}$ reacts rapidly with carbon monoxide to provide the octahedral complex $\left[\mathrm{Os}\left(\mathrm{C}_{6} \mathrm{H}_{4} \mathrm{Me}-4\right) \mathrm{Cl}(\mathrm{CS})(\mathrm{CO})\left(\mathrm{PPh}_{3}\right)_{2}\right]$, with $\mathrm{CS}$ and $\sigma$-tolyl ligands presumably coordinated adjacent to one another. This is supported by the smooth thermal conversion of this compound to the tautomeric species $\left[\mathrm{Os}\left(\eta^{2}-\mathrm{SCC}_{6} \mathrm{H}_{4} \mathrm{Me}-4\right) \mathrm{Cl}(\mathrm{CO})\left(\mathrm{PPh}_{3}\right)_{2}\right]$, 
Scheme $4^{a}$
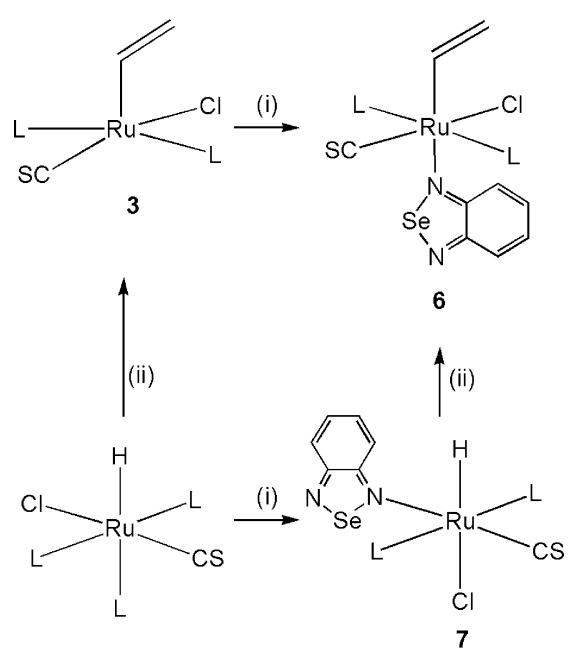

${ }^{a} \mathrm{~L}=\mathrm{PPh}_{3}$. Legend: (i) $\mathrm{BSD}$; (ii) $\mathrm{HC} \equiv \mathrm{CH}$.

which features a $\eta^{2}$-thiatoluoyl ligand. A crystal structure determination of the corresponding trifluoroacetato complex [Os $\left(\eta^{2}-\mathrm{SCC}_{6} \mathrm{H}_{4} \mathrm{Me}-4\right)\left(\mathrm{O}_{2} \mathrm{CCF}_{3}\right)(\mathrm{CO})\left(\mathrm{PPh}_{3}\right)_{2}$ ] confirmed the $\eta^{2}$ formulation. ${ }^{4 a}$ Similar chemistry has been observed for the osmium $\sigma$-alkenyl complex $\left[\mathrm{Os}(\mathrm{CPh}=\mathrm{CHPh}) \mathrm{Cl}(\mathrm{CS})\left(\mathrm{PPh}_{3}\right)_{2}\right]{ }^{7 \mathrm{~b}}$ In contrast, the carbonyl complexes $\left[\mathrm{RuRX}(\mathrm{CO})\left(\mathrm{PPh}_{3}\right)_{2}\right](\mathrm{R}=$ $\sigma$-aryl, ${ }^{16} \sigma$-alkenyl; $\left.{ }^{1} \mathrm{X}=\mathrm{Cl}, \mathrm{Br}, \mathrm{I}\right)$ react with $\mathrm{CO}$ to provide mixtures of either the dicarbonyl complex $\left[\mathrm{RuRX}(\mathrm{CO})_{2}\left(\mathrm{PPh}_{3}\right)_{2}\right]$ or the tautomeric $\eta^{2}$-acyl complex $\left[\mathrm{Ru}\left(\eta^{2}-\mathrm{OCR}\right) \mathrm{X}(\mathrm{CO})\left(\mathrm{PPh}_{3}\right)_{2}\right]$, the position of the equilibrium depending on the nature of $\mathrm{R}$, $\mathrm{X}$, and solvent.

Clearly, addition of BSD to the alkenyl-thiocarbonyl complexes above does not induce migratory insertion coupling of these two ligands. The outcomes of reactions of $\mathbf{1 - 4}$ with carbon monoxide are dependent on the nature of the alkenyl substituents: when the ruthenium $\sigma$-alkenyl complexes $\left[\mathrm{Ru}\left(\mathrm{CR}^{1}=\right.\right.$ $\left.\left.\mathrm{CHR}^{2}\right) \mathrm{Cl}(\mathrm{CS})\left(\mathrm{PPh}_{3}\right)_{2}\right]\left(\mathrm{R}^{1}=\mathrm{R}^{2}=\mathrm{Ph}(\mathbf{1}) ; \mathrm{R}^{1}=\mathrm{H}, \mathrm{R}^{2}=\mathrm{Ph}\right.$ (2); $\left.\mathrm{R}^{1}=\mathrm{R}^{2}=\mathrm{H}(\mathbf{3}) ; \mathrm{R}^{1}=\mathrm{C} \equiv \mathrm{CPh} ; \mathrm{R}^{2}=\mathrm{Ph}(\mathbf{4})\right)$ were treated with carbon monoxide (1 atm), a rapid darkening of the solution to deep red occurred and migrated complexes formulated as $\left[\mathrm{Ru}\left(\eta^{2}-\mathrm{SCCR}^{1}=\mathrm{CHR}^{2}\right) \mathrm{Cl}(\mathrm{CO})\left(\mathrm{PPh}_{3}\right)_{2}\right]\left(\mathrm{R}^{1}=\mathrm{R}^{2}=\mathrm{Ph}(\mathbf{8}) ; \mathrm{R}^{1}\right.$ $=\mathrm{H}, \mathrm{R}^{2}=\mathrm{Ph}(\mathbf{9}) ; \mathrm{R}^{1}=\mathrm{R}^{2}=\mathrm{H}(\mathbf{1 0}) ; \mathrm{R}^{1}=\mathrm{C} \equiv \mathrm{CPh} ; \mathrm{R}^{2}=\mathrm{Ph}$ (11)) could be isolated in high yield. The infrared absorption due to the thiocarbonyl ligand is no longer evident; however, bands of medium intensity at 1332, 1288, 1263, 1193, 966, 929, and $881 \mathrm{~cm}^{-1}$ (Nujol) are observed, which may be attributed to the RuCS metallacycle (Scheme 5). A similar pattern of bands is observed for the osmium ${ }^{4,17}$ and ruthenium ${ }^{18}$ thioaroyl complexes. The thioacyl carbon gives rise to a triplet resonance at $306.0 \mathrm{ppm}\left(J_{\mathrm{CP}}=8.9 \mathrm{~Hz}\right)$ in the ${ }^{13} \mathrm{C}\left\{{ }^{1} \mathrm{H}\right\}$ NMR spectrum of 8, downfield from that assigned to the carbonyl ligand $\left(\delta_{\mathrm{C}} 210.2\right.$, $\left.\mathrm{t}, J_{\mathrm{CP}}=15.2 \mathrm{~Hz}\right)$. The ${ }^{1} \mathrm{H}$ NMR spectrum of $\left[\mathrm{Ru}\left(\eta^{2}-\mathrm{SCCH}=\right.\right.$ $\mathrm{CHPh}) \mathrm{Cl}(\mathrm{CO})\left(\mathrm{PPh}_{3}\right)_{2}$ ] (9) is informative: the $\mathrm{AB}$ pattern $\left(\delta_{\mathrm{H}}\right.$ $6.56,6.35)$ due to the trans- $\beta$-styryl group shows a much reduced difference in the chemical shifts of the two protons, loss of resolvable phosphorus coupling to the low-field doublet, and a modest increase in the value of $J_{\mathrm{AB}}$ to $15.1 \mathrm{~Hz}$, all

(16) (a) Roper, W. R.; Taylor, G. E.; Waters, J. M.; Wright, L. J. J. Organomet. Chem. 1979, 182, C46. (b) Bohle, D. S.; Clark, G. R.; Rickard, C. E. F.; Roper, W. R.; Wright, L. J. J. Organomet. Chem. 1988, 358, 411. (c) Rickard, C. E. F.; Roper, W. R.; Taylor, G. E.; Waters, J. M.; Wright, L. J. J. Organomet. Chem. 1990, 389, 375.

(17) Hill, A. F.; Wilton-Ely, J. D. E. T. J. Chem. Soc., Dalton Trans. 1998, 3501 .

(18) Bedford, R. B.; Hill, A. F.; White, A. J. P.; Williams, D. J. Angew. Chem., Int. Ed. Engl. 1996, 35, 95.
Scheme 5. Alkenyl-Thiocarbonyl Coupling ${ }^{a}$
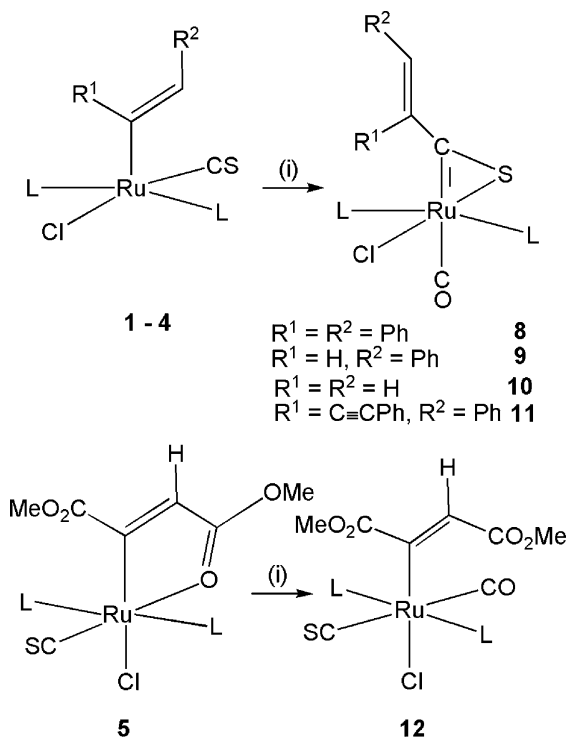

${ }^{a} \mathrm{~L}=\mathrm{PPh}_{3}$. Legend: (i) $\mathrm{CO}$.

consistent with the $\sigma$-alkenyl group now being remote from ruthenium (Scheme 5).

Although a preliminary decolorization of the reaction mixture prior to rapid darkening is sometimes briefly discernible, the failure to more definitely observe or isolate an intermediate octahedral thiocarbonyl complex in the reactions of $\left[\mathrm{Ru}\left(\mathrm{CR}^{1}=\right.\right.$ $\left.\mathrm{CHR}^{2}\right) \mathrm{Cl}(\mathrm{CS})\left(\mathrm{PPh}_{3}\right)_{2}$ ] with carbon monoxide is consistent with the generally recognized acceleration in reaction rates on moving from osmium to ruthenium. In the reaction of the bis(carbomethoxy) derivative $\left[\mathrm{Ru}\left\{\mathrm{C}\left(\mathrm{CO}_{2} \mathrm{Me}\right)=\mathrm{CHCO}_{2} \mathrm{Me}\right\} \mathrm{Cl}\right.$ $\left.(\mathrm{CS})\left(\mathrm{PPh}_{3}\right)_{2}\right]$ (5) with $\mathrm{CO}$, however, no migratory insertion reaction is observed under mild conditions. Instead, the stable octahedral $\sigma$-alkenyl-thiocarbonyl complex $\left[\mathrm{Ru}\left\{\mathrm{C}\left(\mathrm{CO}_{2} \mathrm{Me}\right)=\right.\right.$ $\left.\left.\mathrm{CHCO}_{2} \mathrm{Me}\right\} \mathrm{Cl}(\mathrm{CS})(\mathrm{CO})\left(\mathrm{PPh}_{3}\right)_{2}\right](\mathbf{1 2})$ is isolated. The coordination of carbon monoxide requires that the metallacycle in the precursor be opened to release a free coordination site, and the rapidity of this reaction suggests that this opening is facile. The retardation of the migratory insertion may be traced to two plausible factors. The kinetic site of $\mathrm{CO}$ coordination may be the site cis to the alkenyl ligand liberated by opening of the chelate. If so, this may place the thiocarbonyl trans to the $\sigma$-alkenyl ligand and thus not available for $\mathrm{CS}-$ alkenyl coupling. Alternatively, coordination of $\mathrm{CO}$ trans to the thiocarbonyl ligand would result in the appropriate geometry and, furthermore, the trans disposition of $\mathrm{CS}$ and $\mathrm{CO}$ ligands would especially activate the thiocarbonyl to migratory insertion. Thus, the reticence for migratory insertion is most likely attributable to the increase in $\mathrm{Ru}-\mathrm{C}$ bond strength that results from inclusion of electron-withdrawing methoxycarbonyl substituents, considered to enhance metal-carbon multiple bonding (Chart 2).

The complexes $\left[\mathrm{Ru}\left(\mathrm{CH}=\mathrm{CH}_{2}\right) \mathrm{Cl}(\mathrm{CS})\left(\mathrm{PPh}_{3}\right)_{2}\right](3)$ and $[\mathrm{Ru}-$ $\left.\{\mathrm{C}(\mathrm{C} \equiv \mathrm{CPh})=\mathrm{CHPh}\} \mathrm{Cl}(\mathrm{CS})\left(\mathrm{PPh}_{3}\right)_{2}\right](4)$ both undergo migratory insertion coupling of alkenyl and thiocarbonyl ligands upon carbonylation. In the case of the enynyl species, no resolvable phosphorus coupling with the alkenyl proton resonance is observed. This is in contrast to that seen for the precursor, thus confirming the remoteness of the alkenyl group. The formulation of the complex $\left[\mathrm{Ru}\left\{\eta^{2}-\mathrm{SCC}(\mathrm{C} \equiv \mathrm{CPh})=\mathrm{CHPh}\right\} \mathrm{Cl}(\mathrm{CO})\left(\mathrm{PPh}_{3}\right)_{2}\right]$ (11) was subsequently confirmed by a crystallographic study, the results of which are summarized in Figure 3 and discussed below. 


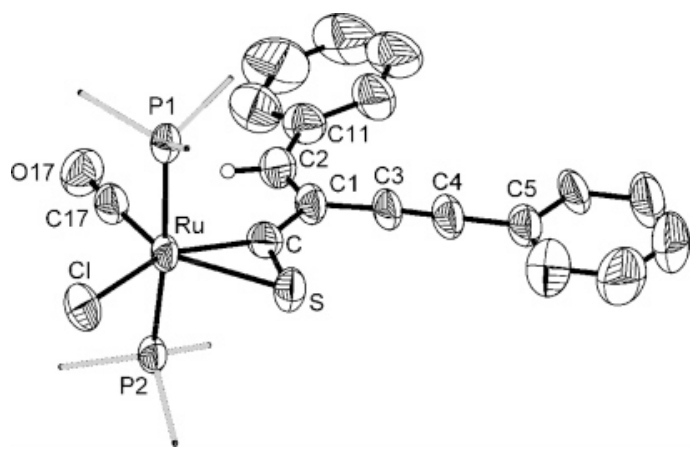

Figure 3. Molecular structure of $\mathbf{1 1}$ (phosphine phenyl rings and phenyl hydrogen atoms omitted, 50\% displacement ellipsoids). Selected bond lengths $(\AA)$ and angles (deg): $\mathrm{Ru}-\mathrm{C}=1.952(7)$, $\mathrm{Ru}-\mathrm{S}=2.552(2), \mathrm{Ru}-\mathrm{Cl}=2.501(2), \mathrm{Ru}-\mathrm{P}(1)=2.407(2), \mathrm{Ru}-$ $\mathrm{P}(2)=2.400(2), \mathrm{Ru}-\mathrm{C}(17)=1.829(10), \mathrm{C}-\mathrm{S}=1.651(11)$, $\mathrm{C}-\mathrm{C}(1)=1.459(12), \mathrm{C}(1)-\mathrm{C}(2)=1.341(13), \mathrm{C}(3)-\mathrm{C} 4)=1.156-$ (12); $\mathrm{C}-\mathrm{Ru}-\mathrm{S}=40.3(3), \mathrm{P}(1)-\mathrm{Ru}-\mathrm{P}(2)=172.05(8), \mathrm{Ru}-\mathrm{C}-\mathrm{S}$ $=89.8(4), \mathrm{Ru}-\mathrm{S}-\mathrm{C}=49.9(3), \mathrm{C}(1)-\mathrm{C}(3)-\mathrm{C}(4)=176.3(11)$.

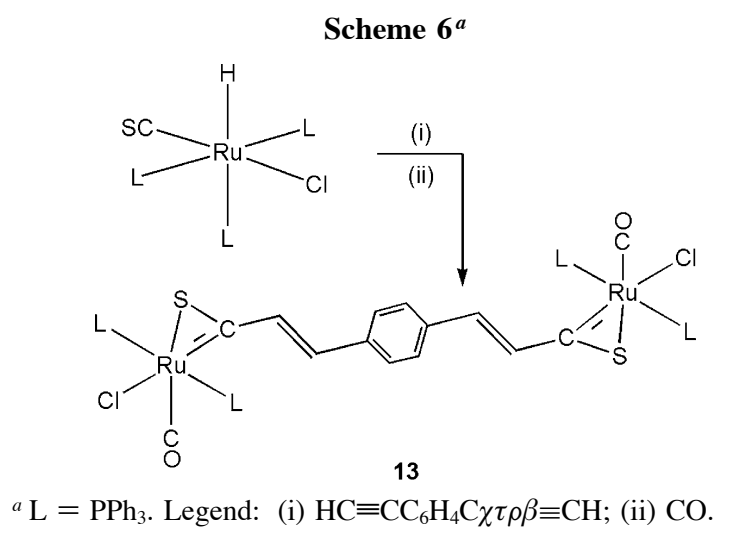

In the chemistry of alkenyl complexes bearing carbonyl ligands, 1,4-diethynylbenzene has been used to prepare dinuclear complexes ${ }^{19}$ and recent studies have investigated the electrochemical properties of the triisopropylphosphine variants. ${ }^{20}$ The conjugation of the $p$-phenylene unit also makes these species attractive for studies of charge-transfer processes. It appeared likely that the methodology described above would provide a route to an unprecedented bis(thioacyl) complex linked by the $p$ - $\mathrm{SCCH}=\mathrm{CH}\left(\mathrm{C}_{6} \mathrm{H}_{4}\right) \mathrm{CH}=\mathrm{CHCS}$ "spacer". Reaction of 2 equiv of $\left[\mathrm{RuHCl}(\mathrm{CS})\left(\mathrm{PPh}_{3}\right)_{3}\right]$ with 1,4-diethynylbenzene led to a purple solution, which ${ }^{31} \mathrm{P}$ NMR spectroscopy revealed to be a mixture of products (likely to include some tris(phosphine) species). Treatment of this solution with carbon monoxide resulted in a darkening of the color to deep red, and from this solution a brown solid was obtained (Scheme 6) and formulated as $\left[\left(\mathrm{PPh}_{3}\right)_{2}(\mathrm{CO}) \mathrm{ClRu}\left(\eta^{2}-\mathrm{SCCH}=\mathrm{CHC}{ }_{6} \mathrm{H}_{4} \mathrm{CH}=\mathrm{CHCS}-\eta^{2}\right) \mathrm{RuCl}-\right.$ $\left.(\mathrm{CO})\left(\mathrm{PPh}_{3}\right)_{2}\right]_{2}(\mathbf{1 3})$. Evidence for this included the presence of a $v_{\mathrm{CO}}$ band at $1918 \mathrm{~cm}^{-1}$ and, more importantly, the absence of a thiocarbonyl absorption in the solid-state infrared spectrum. The only feature observed for the protons of the $p$-phenylene spacer in the ${ }^{1} \mathrm{H}$ NMR spectrum was a singlet at $6.98 \mathrm{ppm}$ (as expected on symmetry grounds) along with resonances for the alkenyl protons at 6.43 and $6.53 \mathrm{ppm}\left(J_{\mathrm{HH}}\right.$ $=15.5 \mathrm{~Hz})$, similar to those observed for $\left[\mathrm{Ru}\left(\eta^{2}-\mathrm{SCH}=\mathrm{CHPh}\right)\right.$ $\left.\mathrm{Cl}(\mathrm{CO})\left(\mathrm{PPh}_{3}\right)_{2}\right](\mathbf{9})$.

(19) (a) Santos, A.; López, J.; Montoya, J.; Noheda, P.; Romero, A.; Echavarren, A. M. Organometallics 1994, 13, 3605. (b) Jia, G.; Wu, W. F.; Yeung, R. C. Y.; Xia, H. P. J. Organomet. Chem. 1997, 539, 53.

(20) Maurer, J.; Sarkar, B.; Schwederski, B.; Kaim, W.; Winter, R. F.; Záliš, S. Organometallics 2006, 25, 3701.
Scheme $7^{a}$
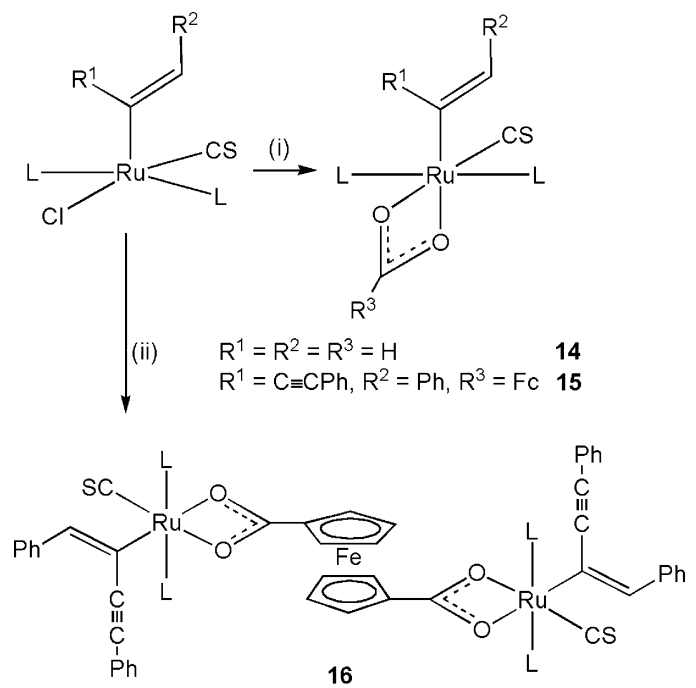

${ }^{a} \mathrm{~L}=\mathrm{PPh}_{3}$. Legend: (i) $\mathrm{Na}\left[\mathrm{O}_{2} \mathrm{CH}\right]$ or $\mathrm{FcCO}_{2} \mathrm{H}, \mathrm{NEt}_{3}(\mathrm{Fc}=$ $\left.\mathrm{CpFeC}_{5} \mathrm{H}_{4}\right)$; (ii) $\mathrm{Fe}\left(\eta^{5}-\mathrm{C}_{5} \mathrm{H}_{4} \mathrm{CO}_{2} \mathrm{H}\right)_{2}, \mathrm{NEt}_{3}$.

The reactions of the complexes [Ru(alkenyl) $\left.\mathrm{Cl}(\mathrm{CO})\left(\mathrm{PPh}_{3}\right)_{2}\right]$ with carboxylates give air-stable coordinatively saturated complexes of the type $\left[\mathrm{Ru}(\right.$ alkenyl $\left.)\left(\kappa^{2}-\mathrm{O}_{2} \mathrm{CR}\right)(\mathrm{CO})\left(\mathrm{PPh}_{3}\right)_{2}\right]$ with no significant side products. ${ }^{1 \mathrm{c}, \mathrm{f}, \mathrm{h}, 21} \mathrm{Bis}$ (carboxylates) therefore presented an alternative approach to the preparation of binuclear complexes. In order to test the reactivity of the thiocarbonylalkenyl complexes with carboxylates, $\left[\mathrm{Ru}\left(\mathrm{CH}=\mathrm{CH}_{2}\right) \mathrm{Cl}(\mathrm{CS})\right.$ $\left(\mathrm{PPh}_{3}\right)_{2}$ ] (3) was treated with sodium formate, resulting in the clean formation of $\left[\mathrm{Ru}\left(\mathrm{CH}=\mathrm{CH}_{2}\right)\left(\kappa^{2}-\mathrm{O}_{2} \mathrm{CH}\right)(\mathrm{CS})\left(\mathrm{PPh}_{3}\right)_{2}\right](\mathbf{1 4})$ through substitution of the chloride ligand and occupation of the vacant site (Scheme 7). The presence of the formate ligand was indicated by a phosphorus-coupled triplet resonance in the ${ }^{1} \mathrm{H}$ NMR spectrum at $7.00 \mathrm{ppm}\left(J_{\mathrm{HP}}=1.8 \mathrm{~Hz}\right)$. The $\mathrm{H}_{\alpha}$ resonance of the ethenyl ligand was obscured by those of the phosphine ligands, but its presence was manifest in coupling to the $\mathrm{H}_{\beta}$ and $\mathrm{H}_{\beta^{\prime}}$ protons, signals for which appear at $\delta_{\mathrm{H}} 4.84$ $(\mathrm{dt})$ and $5.01(\mathrm{dt})$. In addition to the diagnostic $v_{\mathrm{OCO}}$ band at $1547 \mathrm{~cm}^{-1}$, a characteristically strong infrared absorption was observed for the thiocarbonyl ligand at $1274 \mathrm{~cm}^{-1}$ (Nujol), indicating that the halide/formate metathesis does not induce migratory insertion.

An analogous yellow-orange product, $[\mathrm{Ru}\{\mathrm{C}(\mathrm{C} \equiv \mathrm{CPh})=$ $\left.\mathrm{CHPh}\}\left(\kappa^{2}-\mathrm{O}_{2} \mathrm{CFc}\right)(\mathrm{CS})\left(\mathrm{PPh}_{3}\right)_{2}\right]\left(\mathbf{1 5} ; \mathrm{Fc}=\mathrm{CpFeC}_{5} \mathrm{H}_{4}\right)$, was formed in excellent yield from the reaction of enynyl complex 4 with ferrocenecarboxylic acid in the presence of $\mathrm{NEt}_{3}$. Ferrocenemonocarboxylate complexes of ruthenium have previously been reported, ${ }^{22 a}$ including the alkenyl derivative [Ru$\left.\left(\mathrm{CH}=\mathrm{CH}_{2}\right)\left(\mathrm{O}_{2} \mathrm{CFc}\right)(\mathrm{CO})\left(\mathrm{PPh}_{3}\right)_{2}\right]{ }^{22 \mathrm{~b}}$ Characteristic resonances were observed for the enynyl ligand in the ${ }^{1} \mathrm{H}$ NMR spectrum along with pseudotriplets at 3.88 and $4.03 \mathrm{ppm}\left(J_{\mathrm{HH}}=1.65\right.$ $\mathrm{Hz}$ ) for the monosubstituted cyclopentadienyl ring and a singlet at $3.49 \mathrm{ppm}$ for the $\mathrm{C}_{5} \mathrm{H}_{5}$ ligand. The formulation of the complex was subsequently confirmed by elemental analysis and a crystallographic study, the results of which are summarized in Figure 4 and discussed below.

This result paved the way for the synthesis of a trimetallic bridged alkenyl species using 1,1'-ferrocenedicarboxylic acid

(21) Loumrhari, H.; Ros, J.; Yáñez, R.; Torres, M. R. J. Organomet. Chem. 1991, 408, 233.

(22) (a) Matas, L.; Moldes, I.; Soler, J.; Ros, J.; Alvarez-Larena, A. Piniella, J. F. Organometallics 1998, 17, 4551. (b) Wyman, I. W.; Burchell, T. J.; Robertson, K. N.; Cameron, T. S.; Aquino, M. A. S. Organometallics 2004, 23, 5353 . 


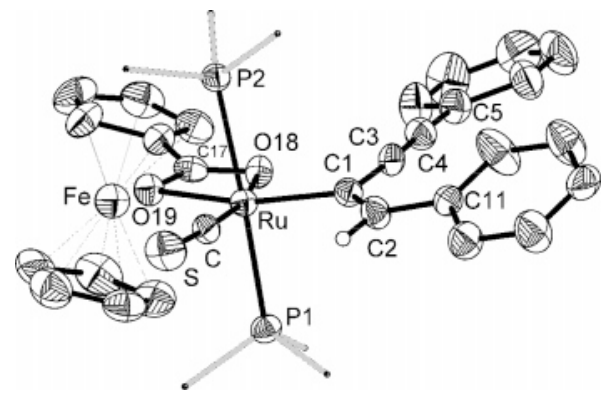

Figure 4. Molecular structure of $\mathbf{1 5}$ (phosphine phenyl groups and cyclopentadienyl and phenyl hydrogen atoms omitted, 50\% displacement ellipsoids). Selected bond lengths $(\AA)$ and angles (deg): $\mathrm{Ru}-\mathrm{C}=1.778(5), \mathrm{Ru}-\mathrm{P}(1)=2.3872(15), \mathrm{Ru}-\mathrm{P}(2)=2.4134$ (15), $\mathrm{Ru}-\mathrm{C}(1)=2.069(5), \mathrm{Ru}-\mathrm{O}(18)=2.250(4), \mathrm{Ru}-\mathrm{O}(19)=$ 2.237(3), $\mathrm{C}-\mathrm{S}=1.565(6), \mathrm{C}(1)-\mathrm{C}(2)=1.346(7), \mathrm{C}(3)-\mathrm{C}(4)=$ $1.182(7) ; \mathrm{P}(1)-\mathrm{Ru}-\mathrm{P}(2)=176.66(5), \mathrm{O}(18)-\mathrm{Ru}-\mathrm{O}(19)=58.16-$ (13), $\mathrm{Ru}-\mathrm{C}-\mathrm{S}=174.4(4), \mathrm{Ru}-\mathrm{C}(1)-\mathrm{C}(2)=129.6(4), \mathrm{C}(1)-$ $\mathrm{C}(3)-\mathrm{C}(4)=172.4(6)$.

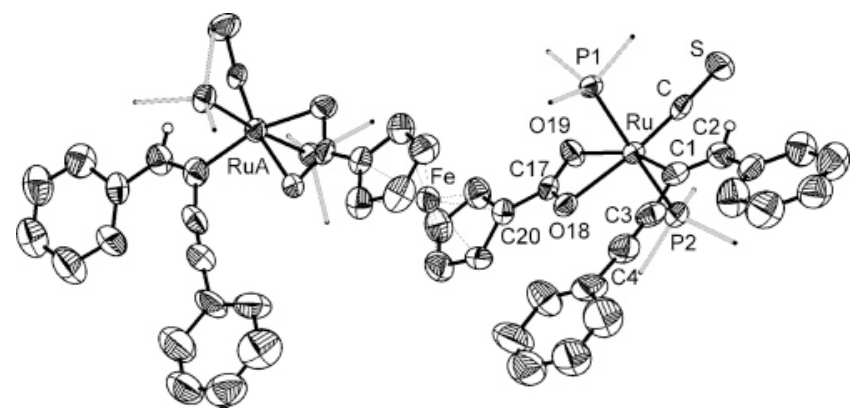

Figure 5. Molecular structure of the complex $\mathbf{1 6}$ (phosphine phenyl groups and cyclopentadienyl and phenyl hydrogen atoms omitted, $50 \%$ displacement ellipsoids). A crystallographic $C_{2}$ axis passes through $\mathrm{Fe}$. Selected bond lengths $(\AA)$ and angles $(\mathrm{deg}): \mathrm{Ru}-\mathrm{C}=$ 1.783(8), $\mathrm{Ru}-\mathrm{P}(2)=2.395(2), \mathrm{Ru}-\mathrm{P}(1)=2.383(2), \mathrm{Ru}-\mathrm{C}(1)=$ 2.053(9), $\mathrm{Ru}-\mathrm{O}(18)=2.253(5), \mathrm{Ru}-\mathrm{O}(19)=2.250(5), \mathrm{C}-\mathrm{S}=$ $1.560(8), \mathrm{C}(1)-\mathrm{C}(2)=1.358(11), \mathrm{C}(3)-\mathrm{C}(4)=1.208(13) ; \mathrm{P}(1)-$ $\mathrm{Ru}-\mathrm{P}(2)=175.23(8), \mathrm{O}(18)-\mathrm{Ru}-\mathrm{O}(19)=58.81(18), \mathrm{Ru}-\mathrm{C}-\mathrm{S}$ $=175.5(5), \mathrm{Ru}-\mathrm{C}(1)-\mathrm{C}(2)=130.0(7), \mathrm{C}(1)-\mathrm{C}(3)-\mathrm{C}(4)=168.7-$ (10).

as the bifunctional linker. Treatment of 2 equiv of 4 with 1 equiv of the dicarboxylic acid in the presence of excess $\mathrm{Et}_{3} \mathrm{~N}$ led to the formation of the trinuclear complex $\mathrm{Fe}\left[\eta^{5}-\mathrm{C}_{5} \mathrm{H}_{4} \mathrm{CO}_{2}\right.$ $\left.\mathrm{Ru}\{\mathrm{C}(\mathrm{C} \equiv \mathrm{CPh})=\mathrm{CHPh}\}(\mathrm{CS})\left(\mathrm{PPh}_{3}\right)_{2}\right]_{2}$ (16). Spectroscopic data similar to those for $\mathbf{1 5}$ were obtained, and the molecular structure of this species was confirmed by a crystallographic study. These results are summarized in Figure 5 and discussed below.

Given the abundance of carboxylic acids available, and the many known mononuclear complexes, ${ }^{1 \mathrm{c}, \mathrm{f}, \mathrm{h}, 15}$ it is perhaps surprising that bridging carboxylate units have not been used to link ruthenium centers in the manner described above. The closest examples are those reported very recently, in which 2 equiv of $\left[\mathrm{Ru}(\operatorname{aryl}) \mathrm{Cl}(\mathrm{CO})\left(\mathrm{PPh}_{3}\right)_{2}\right]\left(\operatorname{aryl}=\mathrm{C}_{6} \mathrm{H}_{2} \mathrm{OH}-2-\mathrm{CHNC}_{6} \mathrm{H}_{4} \mathrm{R}\right.$; $\mathrm{R}=\mathrm{Me}, \mathrm{Cl})$ reacts with disodium terephthalate to give $[\mathrm{Ru}-$ $\left.(\operatorname{aryl})(\mathrm{CO})\left(\mathrm{PPh}_{3}\right)_{2}\right]_{2}\left(\mu-\mathrm{O}_{2} \mathrm{CC}_{6} \mathrm{H}_{4} \mathrm{CO}_{2}\right){ }^{23}$ However, despite an increasing number of polymetallic compexes bridged by the ferrocenedicarboxylate ligand having appeared in recent times, ${ }^{24}$ it is also surprising that none appear to be of the simple dinuclear monobridged form $\left\{\mathrm{L}_{n} \mathrm{MO}_{2} \mathrm{CC}_{5} \mathrm{H}_{4}\right\}_{2} \mathrm{Fe}$ but instead involve polymeric structures or bridged metal-metal multiple bonded bimetallic units.

Structural Discussion. Despite coordinative unsaturation, the complex $\left[\mathrm{Ru}(\mathrm{CPh}=\mathrm{CHPh}) \mathrm{Cl}(\mathrm{CS})\left(\mathrm{PPh}_{3}\right)_{2}\right](\mathbf{1})$ is monomeric, and

(23) Pan, S.; Panda, B. K. J. Indian Chem. Soc. 2005, 82, 16.

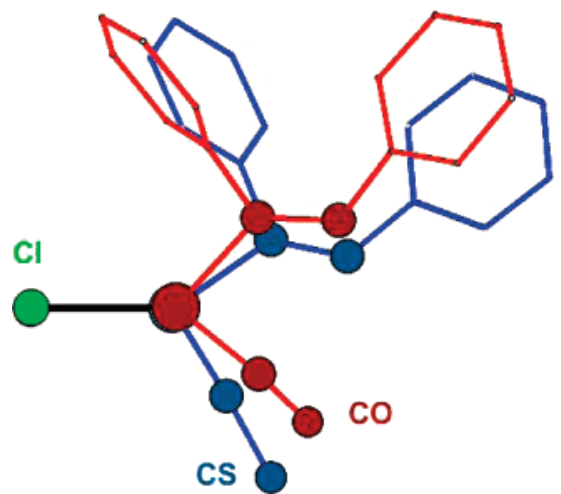

Figure 6. Superposition of the equatorial coordination planes of $\mathrm{Ru}(\mathrm{CPh}=\mathrm{CHPh}) \mathrm{Cl}(\mathrm{CA})\left(\mathrm{PPh}_{3}\right)_{2}\left(\mathrm{~A}=\mathrm{O}^{1 \mathrm{a}}(\right.$ red $), \mathrm{S}$ (blue) $)$.

while it is not isomorphous with the carbonyl analogue, the molecular geometries at ruthenium are superficially similar for both complexes.

The gross coordination geometry at ruthenium may be described as between trigonal bipyramidal (tbp) and squarebased pyramidal (sbp), with an angle of $171.45(6)^{\circ}$ between the ruthenium - phosphorus vectors and $121.7(2)^{\circ}$ for $\mathrm{C}-\mathrm{Ru}-$ $\mathrm{Cl}$. In the case of the corresponding carbonyl analogue, the $\sigma$-vinyl ligand may be described as assuming the apical-sbp site. For 1, this description is less apt, in that the alkenyl ligand makes an angle close to $90^{\circ}\left(93.3(3)^{\circ}\right)$ with the thiocarbonyl ligand and $145.0(2)^{\circ}$ with the chloride. Thus, it would appear that it is the thiocarbonyl ligand that is best described as occupying the apical-sbp site, as illustrated in Figure 6, consistent with both the superlative $\pi$-acidity and trans influence of CS ligands. The plane of the alkenyl linkage is essentially normal to that containing the ruthenium-phosphorus bonds $\left(77.35^{\circ}\right)$, consistent with the ligand adopting a $\pi$-acid role which is maximized in this orientation, in addition to minimizing nonbonding interactions. The assertion of partial multiple bonding between $\mathrm{Ru}$ and $\mathrm{C} 1$ of the alkenyl ligand is supported by a comparatively short $\mathrm{Ru}-\mathrm{C} 1$ separation of 2.045(6) $\AA$, which falls toward the shorter end of the range for $\sigma$-alkenyl ligands bound to divalent ruthenium (Table 1). Furthermore, the vinylic separation of 1.351(8) $\AA$ is somewhat long for such ligands.

Given the comparatively small set of structurally characterized pairs of carbonyl and thiocarbonyl complexes, it is worthwhile to consider the bonding within the equatorial planes of both molecules in more detail (Figure 6 and Table 1). First, the ruthenium-chalcocarbonyl bond is clearly enhanced in the thiocarbonyl complex, with a $2 \%$ decrease in the $\mathrm{Ru}-\mathrm{C}$ bond length relative to that of the analogous carbonyl ligand. On comparison of the ruthenium-alkenyl separations for the two complexes, there is a marginal lengthening of the bond in the thiocarbonyl complex. The ruthenium center is less $\pi$-basic in this complex, due to the enhanced $\pi$-acidity of the thiocarbonyl

(24) (a) Kim, Y. S.; Kim, J.; Kim, D.; Chae, H. K. Chem. Lett. 2007, 36, 150. (b) Yeng, X.; Li, G.; Hou, H.; Han, H.; Fan, Y.; Zhu, Y.; Du, C. J. Organomet. Chem. 2003, 679, 153. (c) Dong, G.; Li, Y.-T.; Duan, C.Y.; Hong, M.; Meng, Q.-J. Inorg. Chem. 2003, 42, 2519. (d) Naksakov, V. A.; Slovohotova, I. V.; Golovin, A. V.; Babailov, S. P. Russ. Chem. Bull. 2001, 50, 2451. (e) Bera, J. K.; Clerac, R.; Fanwick, P. E.; Walton, R. A. Dalton Trans. 2002, 2168. (f) Cotton, F. A.; Donahue, J. P.; Lin, C.; Murillo, C. A. Inorg. Chem. 2001, 40, 1234. (g) Lee, S.-M.; Cheung, K.-K.; Wong, W.-T. J. Organomet. Chem. 1996, 506, 77. (h) Cayton, R. H.; Chisholm, M. H.; Huffman, J. C.; Lobkovsky, E. B. J. Am. Chem. Soc. 1991, 113, 8709. (i) Xiangru, M.; Hongwei, H.; Gang, L.; Baoxian, Y.; Tiezhu, G.; Yaoting, F.; Yu, Z.; Sakiyama, H. J. Organomet. Chem. 2004, 689, 1218. (j) Xiangru, M.; Gang, L.; Hongwei, H.; Huayun, H.; Yaoting, F.; Yu, Z.; Chenxia, D. J. Organomet. Chem. 2003, 679, 153. (k) Dong, G.; Hong, M.; Duan, C.-Y.; Feng, L.; Qing-Jin, M. Dalton Trans. 2002, 2593. 
Table 2. Geometrical Data for Ruthenium and Osmium Thioacyl Complexes ${ }^{a}$

\begin{tabular}{|c|c|c|c|c|}
\hline complex & $\mathrm{M}-\mathrm{C}$ & $\mathrm{M}-\mathrm{S}$ & $\mathrm{C}-\mathrm{S}$ & $\mathrm{S}-\mathrm{Ru}-\mathrm{C}$ \\
\hline$\left[\mathrm{Os}\left(\eta^{2}-\mathrm{SCR}\right)\left(\mathrm{O}_{2} \mathrm{CCF}_{3}\right)(\mathrm{CO}) \mathrm{L}_{2}\right]^{3 \mathrm{a}}$ & $1.91(2)$ & $2.513(6)$ & $1.72(2)$ & $43.0(5)$ \\
\hline$\left[\mathrm{Ru}\left\{\eta^{2}-\mathrm{SCC}(\mathrm{C} \equiv \mathrm{CPh})=\mathrm{CHPh}\right\} \mathrm{Cl}(\mathrm{CO}) \mathrm{L}_{2}\right]$ & $1.952(7)$ & $2.552(2)$ & $1.651(11)$ & $40.3(3)$ \\
\hline$\left[\mathrm{Ru}\left(\eta^{2}-\mathrm{SCSiMe}_{2} \mathrm{OEt}\right) \mathrm{Cl}(\mathrm{CO}) \mathrm{L}_{2}\right]^{5}$ & $1.978(8)$ & $2.545(2)$ & $1.637(8)$ & $40.0(2)$ \\
\hline$\left[\mathrm{Ru}\left(\eta^{2}-\mathrm{SCSMe}\right)(\mathrm{CO})_{2} \mathrm{~L}_{2}\right]^{+34}$ & $2.043(13)$ & $2.459(4)$ & $1.667(13)$ & $42.2(4)$ \\
\hline$\left[\mathrm{Ru}\left(\eta^{2}-\mathrm{SCNMe}_{2}\right) \mathrm{Cl}(\mathrm{CO}) \mathrm{L}_{2}\right]^{35}$ & $1.959(8)$ & $2.548(2)$ & $1.687(9)$ & $41.4(3)$ \\
\hline$\left[\mathrm{Ru}\left(\eta^{2}-\mathrm{SCNMe}_{2}\right)(\mathrm{CO})_{2} \mathrm{~L}_{2}\right]^{+35}$ & $2.047(5)$ & $2.455(2)$ & $1.674(5)$ & $42.5(2)$ \\
\hline$\left[\mathrm{Ru}\left(\eta^{2}-\mathrm{SCPh}\right) \mathrm{Cl}(\mathrm{CS}) \mathrm{L}_{2}{ }^{18}\right.$ & 1.975 & 2.596 & 1.646 & 39.4 \\
\hline$\left[\mathrm{Ru}(\mathrm{SCSMe})(\mathrm{CO})(\mathrm{CNR}) \mathrm{L}_{2}\right]^{+36}$ & $1.99(2)$ & $2.63(2)$ & $1.79(3)$ & $43.7(7)$ \\
\hline
\end{tabular}

${ }^{a} \mathrm{~L}=\mathrm{PPh}_{3} ; \mathrm{R}=\mathrm{C}_{6} \mathrm{H}_{4} \mathrm{Me}-4$. Distances are given in $\AA$ and angles in deg.

Table 3. Selected Bond Data for Divalent Ruthenium $\sigma^{1}$-Enynyl Complexes ${ }^{a}$

\begin{tabular}{|c|c|c|c|c|c|}
\hline complex & $\mathrm{Ru}-\mathrm{C}_{\alpha}$ & $\mathrm{C}_{\alpha}-\mathrm{C}_{\beta}$ & $\mathrm{C}_{\alpha}-\mathrm{C}_{\beta^{\prime}}$ & $\mathrm{C}_{\beta^{\prime}}-\mathrm{C}_{\gamma}$ & $\mathrm{Ru}-\mathrm{C}_{\alpha}-\mathrm{C}_{\beta}$ \\
\hline $\mathrm{Fe}\left[\mathrm{C}_{5} \mathrm{H}_{4} \mathrm{CO}_{2} \mathrm{RuR}(\mathrm{CS}) \mathrm{L}_{2}\right]_{2}(\mathbf{1 6})$ & $2.053(9)$ & $1.358(11)$ & $1.404(12)$ & $1.208(13)$ & $130.0(7)$ \\
\hline$\left[\operatorname{RuR}\left(\mathrm{O}_{2} \mathrm{CFc}\right)(\mathrm{CS}) \mathrm{L}_{2}\right](\mathbf{1 5})$ & $2.069(5)$ & $1.346(7)$ & $1.429(8)$ & $1.182(7)$ & $129.6(4)$ \\
\hline$\left[\operatorname{RuRCl}(\mathrm{CS}) \mathrm{L}_{2}\right](\mathbf{4})$ & $2.027(4)$ & $1.352(6)$ & $1.415(5)$ & $1.211(6)$ & $135.4(3)$ \\
\hline$\left[\mathrm{RuR}\left(\mathrm{O}_{2} \mathrm{CCF}_{3}\right)(\mathrm{CO}) \mathrm{L}_{2}\right]^{37}$ & $2.076(8)$ & $1.354(16)$ & $1.437(12)$ & $1.208(3)$ & $128.5(6)$ \\
\hline$\left[\mathrm{RuR}\left\{\mathrm{HB}(\mathrm{pz})_{3}\right\}(\mathrm{CO}) \mathrm{L}\right]^{38}$ & $2.090(12)$ & $1.374(19)$ & $1.40(2)$ & $1.22(2)$ & $122(1)$ \\
\hline$\left[\mathrm{RuR}\left(\mathrm{C}_{3} \mathrm{H}_{4} \mathrm{NS}_{2}\right)(\mathrm{CO}) \mathrm{L}_{2}\right]^{39}$ & $2.102(2)$ & $1.361(3)$ & $1.420(3)$ & $1.205(3)$ & $126.48(17)$ \\
\hline$\left[\mathrm{RuR} / \mathrm{Cl}(\mathrm{CO}) \mathrm{L}_{2}\right]^{12 \mathrm{c}}$ & $2.109(4)$ & $1.336(5)$ & $1.422(5)$ & $1.207(6)$ & $135.4(3)$ \\
\hline$\left[\mathrm{RuR}\left(\mathrm{C}_{9} \mathrm{H}_{12} \mathrm{NS}\right)(\mathrm{CO}) \mathrm{L}_{2}\right]^{26}$ & $2.111(3)$ & $1.362(3)$ & $1.428(4)$ & $1.199(3)$ & $124.74(19)$ \\
\hline$\left[\mathrm{RuR}\left(\mathrm{C}_{4} \mathrm{H}_{4} \mathrm{~N}_{3} \mathrm{~S}\right)(\mathrm{CO}) \mathrm{L}_{2}\right]^{28}$ & $2.111(4)$ & $1.340(5)$ & $1.421(6)$ & $1.205(6)$ & $126.1(3)$ \\
\hline$\left[\mathrm{RuR}{ }^{\prime \prime} \mathrm{Cl}(\mathrm{CO})_{2} \mathrm{~L}_{2} 40\right.$ & $2.155(3)$ & $1.372(4)$ & $1.397(4)$ & $1.223(4)$ & $125.8(2)$ \\
\hline$\left[\operatorname{RuR}(\mathrm{dppm})(\mathrm{Ind})^{41}\right.$ & $2.094(7)$ & $1.349(10)$ & $1.422(11)$ & $1.182(10)$ & $129.3(6)$ \\
\hline
\end{tabular}

${ }^{a} \mathrm{R}=\mathrm{C}_{\alpha}\left(\mathrm{C}_{\beta} \equiv \mathrm{C}_{\gamma} \mathrm{Ph}\right)=\mathrm{C}_{\beta} \mathrm{HPh}, \mathrm{R}^{\prime}=\mathrm{C}_{\alpha}\left(\mathrm{C}_{\beta} \equiv \mathrm{C}_{\gamma}{ }^{\mathrm{t}} \mathrm{Bu}\right)=\mathrm{C}_{\beta} \mathrm{H}^{\mathrm{t} B u} ; \mathrm{R}^{\prime \prime}=\mathrm{C}_{\alpha}\left(\mathrm{C}_{\beta}=\mathrm{C}_{\gamma} \mathrm{X}\right)=\mathrm{C}_{\beta} \mathrm{HX}\left(\mathrm{X}=\mathrm{C} \equiv \mathrm{W}(\mathrm{CO})_{2} \mathrm{HB}\left(\mathrm{pzMe}_{2}\right)_{3}\right) ; \mathrm{Ind}=\eta^{5}-\mathrm{C}_{9} \mathrm{H}_{7} ; \mathrm{L}=\mathrm{PPh}_{3}$. Distances are given in $\AA$ and angles in deg.

ligand, and this might be expected to be reflected in a compromise of any retrodonation from ruthenium to the alkenyl ligand.

A comparison of the stereochemistry of the equatorial planes of the two complexes in addition to related arrangements for the complexes $\left[\mathrm{Ru}\left(\mathrm{C}_{6} \mathrm{H}_{4} \mathrm{Me}-n\right) \mathrm{Cl}(\mathrm{CO})\left(\mathrm{PPh}_{3}\right)_{2}\right](n=2,4)^{11 \mathrm{c}}$ indicates that the energies involved in moving between the ideal trigonal-bipyramidal and square-based-pyramidal geometries (the latter calculated to be favored for $\mathrm{d}^{6}$ configurations ${ }^{25}$ ) must be small and may well be of a magnitude comparable to intramolecular packing forces. Furthermore, there are clear indications that the coordinative unsaturation in these complexes may be at least partially stabilized by weak interactions with ortho hydrogen atoms of the phosphine ligands.

A similar structure midway between tbp and sbp is found for $\left[\mathrm{Ru}\{\mathrm{C}(\mathrm{C} \equiv \mathrm{CPh})=\mathrm{CHPh}\} \mathrm{Cl}(\mathrm{CS})\left(\mathrm{PPh}_{3}\right)_{2}\right]$ (4). A difference between the structures is the slightly shorter $\mathrm{Ru}(1)-\mathrm{C}(1)$ distance of 2.027(4) $\AA$ in 4 (cf. 1). The geometries of the alkyne carbons $\mathrm{C}(2)$ and $\mathrm{C}(3)$ are appreciably nonlinear, with the $\mathrm{C} \equiv$ $\mathrm{C}$ triple bond being bent slightly toward the metal atom. The $\mathrm{Ru} \cdots \mathrm{C}(2)$ and $\mathrm{Ru} \cdots \mathrm{C}(3)$ distances are 2.615(4) and 3.383(4) $\AA$, with angles at C2 and C3 being $170.0(4)$ and $175.7(4)^{\circ}$, respectively.

The thioacyl complex $\left[\mathrm{Ru}\left\{\eta^{2}-\mathrm{SCC}(\mathrm{C} \equiv \mathrm{CPh})=\mathrm{CHPh}\right\} \mathrm{Cl}(\mathrm{CO})\right.$ $\left.\left(\mathrm{PPh}_{3}\right)_{2}\right](11)$ is monomeric in the crystal, with no significant intermolecular contacts. Considering the thioacyl to occupy one coordination site, the gross geometry may be described as a mildly distorted trigonal bipyramid with trans-axial phosphine ligands $\left(\mathrm{P} 1-\mathrm{Ru}-\mathrm{P} 2=172.05(8)^{\circ}\right)$. The orientations of the equatorial atoms of the first coordination sphere are such that $\pi$-donors ( $\mathrm{S}$ and $\mathrm{Cl}$ ) are pseudo-trans to $\pi$-acidic groups (carbonyl $\mathrm{C} 7$ and acyl carbon $\mathrm{C}$ ), thereby maximizing synergy in $\pi$-interactions. Within the metallathiirene unit there is clear multiple bonding between $\mathrm{C}$ and $\mathrm{Ru}(1.952(7) \AA$ ) and $\mathrm{C}$ and $\mathrm{S}$ (1.651(11) $\AA$ ). These data are consistent with contributions from both the thioacyl (B, Chart 1) and the metallathiirene $(\mathbf{C}$, Chart

(25) (a) Pearson, R. G. J. Am. Chem. Soc. 1969, 91, 4947. (b) Hoffman, P. R.; Caulton, K. G. J. Am. Chem. Soc. 1975, 97, 4221.
1) canonical forms. The failure of the complex to coordinate further ligands by opening the metallacycle might, however, argue for a more substantial contribution from form $\mathbf{C}$.

Data for related group 8 "metallathiirenes" $3 \mathrm{a}, \mathrm{c}, 28$ are collected in Table 2, and these suggest that geometrical changes within the metallacycle are more responsive to variations in the thioacyl substituent than to the metal or complex charge. These inferences should be made with caution, given the limited amount of structural data so far available.

The compound $\left[\mathrm{Ru}\{\mathrm{C}(\mathrm{C} \equiv \mathrm{CPh})=\mathrm{CHPh}\}\left(\kappa^{2}-\mathrm{O}_{2} \mathrm{CFc}\right)(\mathrm{CS})\right.$ $\left(\mathrm{PPh}_{3}\right)_{2}$ ] (15) displays close to octahedral geometry about the ruthenium center with cis interligand angles in the range 83.66(10) $-106.25(19)^{\circ}$. The $\mathrm{Ru}-\mathrm{C} 1$ and $\mathrm{C} 1-\mathrm{C} 2$ bond distances are compared with those of other enynyl complexes, in which the alkenyl ligand is bound directly to ruthenium in a monodentate manner, in Table 3. The enynyl group (excluding the phenyl substituents) in compound $\mathbf{1 5}$ lies in the same plane as the ferrocenecarboxylate chelate, the thiocarbonyl ligand, and the metal center. The alkenyl group substituents are arranged in an $E$ configuration as a corollary of the synthetic route, rather than a manifestation of steric or electronic factors. The $\mathrm{O} 18-\mathrm{Ru}-$ O19 angle of $58.16(13)^{\circ}$ is essentially comparable (8 esd) to that of 59.24(13) ${ }^{\circ}$ reported for the related carboxylate complex $\left[\mathrm{Ru}(\mathrm{CR}=\mathrm{CHR})\left(\mathrm{O}_{2} \mathrm{CCH}=\mathrm{CMe}_{2}\right)(\mathrm{CO})\left(\mathrm{PPh}_{3}\right)_{2}\right]\left(\mathrm{R}=\mathrm{CO}_{2} \mathrm{Me}\right){ }^{1 \mathrm{~d}}$ It is also worth noting that while the $\mathrm{Ru}-\mathrm{O}$ bond distance trans to the carbonyl ligand in this carboxylate complex is similar to that found in 15, the length of the $\mathrm{Ru}-\mathrm{O} 17$ bond (trans to alkenyl, 2.237(4) $\AA$ ) is somewhat greater than the corresponding $\mathrm{Ru}-\mathrm{O}$ bond in the literature complex (2.161(3) $\AA, 23$ esd). This might be explained by the greater $\pi$-acidity of the carbomethoxy groups (cf. $\mathrm{Ph}$ and $\mathrm{C} \equiv \mathrm{CPh}$ ) being transmitted through the vinyl ligand, thereby enhancing any $\pi$-dative component of the carboxylate binding. The geometry at the alkynyl substituent is

(26) Wilton-Ely, J. D. E. T.; Wang, M.; Honarkhah, S.; Tocher, D. A. Inorg. Chim. Acta 2005, 358, 3218.

(27) Torres, M. R.; Santos, A.; Perales, A.; Ros, J. J. Organomet. Chem. 1988, 353, 221.

(28) Wilton-Ely, J. D. E. T.; Pogorzelec, P. J.; Honarkhah, S.; Reid, D. H.; Tocher, D. A. Organometallics 2005, 24, 2862. 
close to linear, with a $\mathrm{C} 1-\mathrm{C} 3-\mathrm{C} 4$ angle of $172.4(6)^{\circ}$. The $\mathrm{P} 1-$ $\mathrm{Ru}-\mathrm{P} 2$ angle of $176.66(5)^{\circ}$ is also close to linear, indicating that there is little steric interaction between the ferrocenyl group and the phenyl substituents on the phosphines. The $\mathrm{Ru}-\mathrm{C}$ bond length for the thiocarbonyl ligand of 1.778(5) $\AA$ might be expected to be considerably shorter than that for the $\mathrm{Ru}-\mathrm{CO}$ bond $(1.808(4) \AA)$ in $\left[\mathrm{Ru}(\mathrm{CR}=\mathrm{CHR})\left(\mathrm{O}_{2} \mathrm{CCH}=\mathrm{CMe}_{2}\right)(\mathrm{CO})\right.$ $\left.\left(\mathrm{PPh}_{3}\right)_{2}\right]\left(\mathrm{R}=\mathrm{CO}_{2} \mathrm{Me}\right)$; however, these are essentially comparable (within 7 esd).

The two ruthenium centers in the trinuclear compound $\mathrm{Fe}$ $\left[\mathrm{C}_{5} \mathrm{H}_{4} \mathrm{CO}_{2} \mathrm{Ru}\{\mathrm{C}(\mathrm{C} \equiv \mathrm{CPh})=\mathrm{CHPh}\}(\mathrm{CS})\left(\mathrm{PPh}_{3}\right)_{2}\right]_{2}(\mathbf{1 6})$ are crystallographically identical (being related by a rotation axis) and display an octahedral geometry with cis interligand angles between $86.08(15)$ and $108.2(3)^{\circ}$, the shortest being due to the carboxylate chelate bite. The geometrical data for the complex are similar to those for $\mathbf{1 5}$. There is a slight distortion from linearity along the $\mathrm{Ru}-\mathrm{Fe}-\mathrm{Ru}^{\prime}$ axis, causing the ferrocenyl $\mathrm{Cp}$ rings to show an eclipsed configuration. This effect is most likely due to crystal-packing constraints rather than any steric interaction of the enynyl groups which are placed on the same side of the $\mathrm{Ru}-\mathrm{Fe}-\mathrm{Ru}^{\prime}$ axis.

\section{Concluding Remarks}

While the hydroruthenation chemistry of $\left[\mathrm{RuHCl}(\mathrm{CS})\left(\mathrm{PPh}_{3}\right)_{2}-\right.$ (L)] $\left(\mathrm{L}=\mathrm{PPh}_{3}, \mathrm{BSD}\right)$ appears to parallel that observed for $\left[\mathrm{RuHCl}(\mathrm{CO})\left(\mathrm{PPh}_{3}\right)_{2}(\mathrm{~L})\right]$, the reactions of the compounds produced with $\mathrm{CO}$ are dominated by the greater propensity of the thiocarbonyl ligand to participate in migratory insertion reactions. The metal-carbon bond strength of carbon monosulfide exceeds that of carbon monoxide due to more efficient $\sigma$-donation and $\pi$-retrodonation. However, it is the latter feature (lowlying $\pi^{*}$ orbitals of CS) that also make the $\mathrm{M}-\mathrm{C}$ bond more reactive, in the present case with respect to migratory insertion. These factors might also be expected to be reflected in the relative $\mathrm{M}-\mathrm{C}$ interactions of $\eta^{2}$ acyl vs thioacyl ligands, wherein one $d(\pi)-p(\pi)$ retrodative interaction is retained. However, the interaction between sulfur and the soft ruthenium or osmium centers and the accompanying reduction in $C-S p(\pi)-p(\pi)$ multiple bonding are presumably also important factors. ${ }^{42}$ Two diruthenium alkenyl complexes have also been prepared using different approaches. Both made use of the potential for further

(29) López, J.; Santos, A.; Romero, A.; Echavarren, A. M. J. Organomet. Chem. 1993, 443, 221.

(30) Hill, A. F.; White, A. J. P.; Williams, D. J.; Wilton-Ely, J. D. E. T. Organometallics 1998, 17, 4249.

(31) Cannadine, J. C.; Hill, A. F.; White, A. J. P.; Williams, D. J.; WiltonEly, J. D. E. T. Organometallics 1996, 15, 5409.

(32) Bruce, M. I.; Duffy, D. N.; Humphrey, M. G.; Swincer, A. G. J. Organomet. Chem. 1985, 282, 385.

(33) López, J.; Romero, A.; Santos, A.; Vegas, A.; Echavarren, A. M.; Noheda, P. J. Organomet. Chem. 1989, 373, 249.

(34) Clark, G. R.; Collins, T. J.; James, S. M.; Roper, W. R. J. Organomet. Chem. 1977, 125, C23.

(35) Hill, A. F.; Tocher, D. A.; Whiet, A. J. P.; Williams, D. J.; WiltonEly, J. D. E. T. Organometallics 2005, 24, 5342.

(36) Boniface, S. M.; Clark, G. R. J. Organomet. Chem. 1980, 184, 125. (37) Dobson, A.; Moore, D. S.; Robinson, S. D.; Hursthouse, M. B.; New, L. Polyhedron 1985, 4, 1119.

(38) Alcock, N. W.; Hill, A. F.; Melling, R. P. Organometallics 1991, 10,3898 .

(39) Wilton-Ely, J. D. E. T.; Wang, M.; Benoit, D. M.; Tocher, D. A. Eur. J. Inorg. Chem. 2006, 3068.

(40) Dewhurst, R. D.; Hill, A. F.; Smith, M. K. Organometallics 2005 , $24,6295$.

(41) Bassetti, M.; Marini, S.; Diaz, J.; Gamasa, M. P.; Gimeno, J.; Rodriguez-Alvarez, Y.; Garcia-Granda, S. Organometallics 2002; 21, 4815.

(42) Headford, C. E. L.; Roper, W. R. In Reactions of Coordinated Ligands; Braterman, P. S., Ed.; Plenum Press: New York, 1985; Vol. 1, pp 513-552. functionalization of the 16-electron thiocarbonyl alkenyl complexes $\left[\mathrm{RuRCl}(\mathrm{CS})\left(\mathrm{PPh}_{3}\right)_{3}\right]\left(\mathrm{R}=\mathrm{CH}=\mathrm{CH}_{2}, \mathrm{CC} \equiv \mathrm{CPh}=\mathrm{CHPh}\right)$, either through the substituent of the alkenyl group or the vacant site at the metal center. Crystallographic studies show that the trimetallic complex $\mathrm{Fe}\left[\kappa^{2}-\mathrm{C}_{5} \mathrm{H}_{4} \mathrm{CO}_{2} \mathrm{Ru}\{\mathrm{C}(\mathrm{C} \equiv \mathrm{CPh})=\mathrm{CHPh}\}\right.$ $\left.(\mathrm{CS})\left(\mathrm{PPh}_{3}\right)_{2}\right]_{2}$ hinges on the iron atom of the ferrocenylcarboxylate ligand while the rigidity of the spacer ligand in the species $\left[\left(\mathrm{Ph}_{3} \mathrm{P}\right)_{2}(\mathrm{OC}) \mathrm{ClRu}\left(\eta^{2}-\mathrm{SCCH}=\mathrm{CHC}_{6} \mathrm{H}_{4} \mathrm{CH}=\mathrm{CHCS}-\eta^{2}\right)\right.$ $\left.\mathrm{RuCl}(\mathrm{CO})\left(\mathrm{PPh}_{3}\right)_{2}\right]_{2}$ ensures a linear rigid-rod arrangement.

\section{Experimental Section}

General Comments. All experiments were carried out under aerobic conditions unless otherwise stated. The majority of the complexes appear indefinitely stable toward the atmosphere in solution or in the solid state, with the exception of the intermediate $\alpha, \omega$-divinyl intermediate in the synthesis of $\mathbf{1 3}$, which slowly deteriorates in solution. Solvents were used as received from commercial sources. The complexes $\left[\mathrm{RuCl}\left(\kappa^{2}-\mathrm{O}_{2} \mathrm{CH}\right)(\mathrm{CS})\left(\mathrm{PPh}_{3}\right)_{2}\right]$ and $\left[\mathrm{RuHCl}(\mathrm{CS})\left(\mathrm{PPh}_{3}\right)_{3}\right]$ have been described elsewhere. ${ }^{11}$ Infrared and FAB-MS data were obtained using Mattson Research Series FT-IR and Autospec Q instruments, respectively. Characteristic phosphine-associated infrared data are not reported. NMR spectroscopy was performed in $\mathrm{CDCl}_{3}$ at $25{ }^{\circ} \mathrm{C}$ using a JEOL JNM EX270 spectrometer. Virtual triplet ${ }^{13} \mathrm{C}$ NMR resonances are written as $\mathrm{t}^{\mathrm{v}}$, and these indicate a trans disposition of phosphine ligands (with "apparent" couplings quoted). All couplings are in hertz. Elemental analysis data were obtained from the Imperial College Microanalytical service or SACS at London Metropolitan University. Light petroleum refers to the petroleum ether fraction of boiling point range $40-60{ }^{\circ} \mathrm{C}$. The procedures given provide materials of sufficient purity for synthetic and spectroscopic purposes. Samples were recrystallized from a mixture of dichloromethane and ethanol for elemental analysis. Solvates were confirmed by integration of the ${ }^{1} \mathrm{H}$ NMR spectrum.

Preparation of $\left[\mathrm{Ru}(\mathrm{CPh}=\mathrm{CHPh}) \mathrm{Cl}(\mathrm{CS})\left(\mathrm{PPh}_{3}\right)_{2}\right]$ (1). (a) $\mathrm{A}$ solution of $\left[\mathrm{RuHCl}(\mathrm{CS})\left(\mathrm{PPh}_{3}\right)_{3}\right](200 \mathrm{mg}, 0.207 \mathrm{mmol})$ in tetrahydrofuran $(10 \mathrm{~mL})$ was treated with diphenylacetylene $(70 \mathrm{mg}, 0.393$ $\mathrm{mmol}$ ) and heated under reflux for $10 \mathrm{~min}$. The solution was cooled, diluted with ethanol $(30 \mathrm{~mL})$, and concentrated under reduced pressure to provide orange crystals which were isolated by filtration, washed with ethanol $(2 \times 10 \mathrm{~mL})$ and light petroleum $(10 \mathrm{~mL})$, and dried under vacuum. Yield: $140 \mathrm{mg}(77 \%)$.

(b) A suspension of $\left[\mathrm{RuCl}\left(\kappa^{2}-\mathrm{O}_{2} \mathrm{CH}\right)(\mathrm{CS})\left(\mathrm{PPh}_{3}\right)_{2}\right](200 \mathrm{mg}, 0.267$ $\mathrm{mmol}$ ) and diphenylacetylene (70 $\mathrm{mg}, 0.393 \mathrm{mmol})$ in ethanol (20 $\mathrm{mL}$ ) was heated under reflux for $1 \mathrm{~h}$. The orange suspension was left to cool for $1 \mathrm{~h}$ and the orange microcrystalline product isolated by filtration, washed with ethanol $(2 \times 10 \mathrm{~mL})$ and light petroleum (10 mL), and dried under vacuum. Yield: $190 \mathrm{mg}(81 \%)$. Further material (ca. 5\%) could be obtained by removal of solvent from the filtrate and crystallization of the residue from a mixture of chloroform and ethanol. IR (Nujol, $\mathrm{cm}^{-1}$ ): 1596, 1586, 1570, 1564, $1290 v_{\mathrm{CS}}, 1153,970,921,875,842,829,791 .{ }^{1} \mathrm{H}$ NMR: $5.64(\mathrm{~s}$ (br), $1 \mathrm{H}, \mathrm{RuC}=\mathrm{CH}), 6.47,\left(\mathrm{~d} \times 2,2 \mathrm{H}, \mathrm{H}^{2,6}\left(\mathrm{CC}_{6} \mathrm{H}_{5}\right), J_{\mathrm{HH}}=7.6\right)$, $6.90\left(\mathrm{~m}, 2 \mathrm{H}, \mathrm{H}^{3,5}\left(\mathrm{CC}_{6} \mathrm{H}_{5}\right)\right), 7.20\left(\mathrm{t}, 1 \mathrm{H}, \mathrm{H}^{4}\left(\mathrm{CC}_{6} \mathrm{H}_{5}\right), J_{\mathrm{HH}}=7.4\right)$, 7.26-7.56 (m, $\left.35 \mathrm{H}, \mathrm{PC}_{6} \mathrm{H}_{5}+\mathrm{CC}_{6} \mathrm{H}_{5}\right)$ ppm. ${ }^{13} \mathrm{C}\left\{{ }^{1} \mathrm{H}\right\}$ NMR: 301.2 $\left(\mathrm{t}, \mathrm{CS}, J_{\mathrm{CP}}=17.0\right), 166.1\left(\mathrm{t}, \mathrm{RuCPh}, J_{\mathrm{CP}}=9.0\right), 138.8(\mathrm{~s}(\mathrm{br})$, $\mathrm{C}^{1}\left(\mathrm{CC}_{6} \mathrm{H}_{5}\right), J_{\mathrm{PC}}$ not resolved $), 136.3\left(\mathrm{t}^{\mathrm{v}}, o-/ m-\mathrm{PC}_{6} \mathrm{H}_{5}, J_{\mathrm{PC}}=5.4\right)$, $133.9\left(\mathrm{t}^{\mathrm{v}}, o-/ m-\mathrm{PC}_{6} \mathrm{H}_{5}, J_{\mathrm{PC}}=5.4\right), 137.2-127.3(\mathrm{~m}$, remaining $\mathrm{PC}_{6} \mathrm{H}_{6}, \mathrm{CC}_{6} \mathrm{H}_{5}$ and $\mathrm{CHPh}$ ) ppm. ${ }^{31} \mathrm{P}\left\{{ }^{1} \mathrm{H}\right\}$ NMR: 31.3 ppm. FABMS: $m / z$ (\% abundance) $884(15)[\mathrm{M}]^{+}, 849(26)[\mathrm{M}-\mathrm{Cl}]^{+}, 705$ (8) $[\mathrm{M}-\text { alkenyl }]^{+}, 670$ (32) $[\mathrm{M}-\mathrm{Cl}-\text { alkenyl }]^{+}, 622$ (7) $[\mathrm{M}-$ $\left.\mathrm{PPh}_{3}\right]^{+}, 586(60)\left[\mathrm{M}-\mathrm{Cl}-\mathrm{PPh}_{3}\right]^{+}, 407$ (24) $\left[\mathrm{Ru}(\mathrm{CS})\left(\mathrm{PPh}_{3}\right)\right]^{+}$, 363 (24) $\left[\mathrm{RuPPh}_{3}\right]^{+}$. Anal. Found: C, 61.7; H, 4.1. Calcd for $\mathrm{C}_{51} \mathrm{H}_{41} \mathrm{ClP}_{2} \mathrm{RuS} \cdot \mathrm{CHCl}_{3}$ : C, 62.2; H, 4.2.

The complex $\left[\mathrm{Ru}\left\{\mathrm{C}\left(\mathrm{C}_{6} \mathrm{H}_{4} \mathrm{Me}-4\right)=\mathrm{CHC}_{6} \mathrm{H}_{4} \mathrm{Me}-4\right\} \mathrm{Cl}(\mathrm{CS})\left(\mathrm{PPh}_{3}\right)_{2}\right]$ was also prepared in comparable yield for NMR purposes by a 
completely analogous procedure, with diphenylacetylene being replaced by di-p-tolylacetylene: a solution of $\left[\mathrm{RuHCl}(\mathrm{CS})\left(\mathrm{PPh}_{3}\right)_{3}\right]$ (200 mg, $0.207 \mathrm{mmol})$ in tetrahydrofuran $(20 \mathrm{~mL})$ was treated with di-p-tolylacetylene ( $85 \mathrm{mg}, 0.412 \mathrm{mmol}$ ) and the resulting mixture heated under reflux for $2.5 \mathrm{~h}$ and then cooled to room temperature. Ethanol $(30 \mathrm{~mL})$ was added and the mixture concentrated under reduced pressure to ca. $10 \mathrm{~mL}$. The crude brown precipitate was isolated by filtration and recrystallized from a mixture of dichloromethane and ethanol. Yield: $145 \mathrm{mg}$ (77\%). IR (Nujol): 1278 $v_{\mathrm{CS}}, 1187,1158,807 \delta\left(\mathrm{C}_{6} \mathrm{H}_{4}\right) \mathrm{cm}^{-1} .{ }^{1} \mathrm{H}$ NMR: 2.20 (s, $\left.3 \mathrm{H}, \mathrm{Me}\right)$, $2.21(\mathrm{~s}, 3 \mathrm{H}, \mathrm{Me}), 5.57(\mathrm{~s}(\mathrm{br}), 1 \mathrm{H},=\mathrm{CH}), 6.29,6.48(\mathrm{AB}, 4 \mathrm{H}$, $\left.\mathrm{C}_{6} \mathrm{H}_{4}, J_{\mathrm{AB}}=7.9\right), 6.63,6.77\left(\mathrm{AB}, 4 \mathrm{H}, \mathrm{C}_{6} \mathrm{H}_{4}, J_{\mathrm{AB}}=7.9\right), 7.09-$ $7.70\left(\mathrm{~m}, 30 \mathrm{H}, \mathrm{PC}_{6} \mathrm{H}_{5}\right) .{ }^{31} \mathrm{P}\left\{{ }^{1} \mathrm{H}\right\}$ NMR: $31.2 \mathrm{ppm}$.

Preparation of $\left[\mathrm{Ru}(\mathrm{CH}=\mathrm{CHPh}) \mathrm{Cl}(\mathrm{CS})\left(\mathrm{PPh}_{3}\right)_{2}\right]$ (2). A solution of $\left[\mathrm{RuHCl}(\mathrm{CS})\left(\mathrm{PPh}_{3}\right)_{3}\right](200 \mathrm{mg}, 0.207 \mathrm{mmol})$ in dichloromethane $(10 \mathrm{~mL})$ was treated with phenylacetylene $(0.15 \mathrm{~mL}, 1.371 \mathrm{mmol})$ and stirred for $10 \mathrm{~min}$. The solution was diluted with ethanol (40 $\mathrm{mL}$ ) and stirred for a further $15 \mathrm{~min}$. Red crystals of the product were isolated by filtration, washed with ethanol $(2 \times 10 \mathrm{~mL})$ and light petroleum $(10 \mathrm{~mL})$, and dried under vacuum. Yield: $120 \mathrm{mg}$ (72\%). IR (Nujol): 1593, 1585, 1571, 1565, 1552, 1285, $1270 v_{\mathrm{CS}}$, 1148, 973, 963, 950, 930, 921, $800 \mathrm{~cm}^{-1} .{ }^{1} \mathrm{H}$ NMR $\left(\mathrm{C}_{6} \mathrm{D}_{6}\right): 6.15$ $\left(\mathrm{d}, 1 \mathrm{H},=\mathrm{C}_{\beta} \mathrm{H}, J_{\mathrm{HH}}=14.1\right), 6.83-7.13,7.85-7.95(\mathrm{~m} \times 2,30 \mathrm{H}$ $\left.+5 \mathrm{H}, \mathrm{C}_{6} \mathrm{H}_{5}\right), 8.65\left(\mathrm{dt}, 1 \mathrm{H}, \mathrm{RuCH}, J_{\mathrm{HH}}=14.1, J_{\mathrm{HP}}=2.9\right) \mathrm{ppm}$. ${ }^{31} \mathrm{P}\left\{{ }^{1} \mathrm{H}\right\}$ NMR: $33.5 \mathrm{ppm}$. FAB-MS: $\mathrm{m} / \mathrm{z}$ (\% abundance) $808(1)$ $[\mathrm{M}]^{+}, 773(11)[\mathrm{M}-\mathrm{Cl}]^{+}, 705$ (2) $[\mathrm{M}-\text { alkenyl }]^{+}, 671$ (1) $[\mathrm{M}-$ $\mathrm{Cl}$ - alkenyl $]^{+}, 626(1)\left[\mathrm{Ru}\left(\mathrm{PPh}_{3}\right)_{2}\right]^{+}, 443$ (4) $[\mathrm{M}$ - alkenyl $\left.\mathrm{PPh}_{3}\right]^{+}, 397$ (4) $\left[\mathrm{RuClPPh}_{3}\right]^{+}, 365(10)\left[\mathrm{RuPPh}_{3}\right]^{+}$. Anal. Found: C, 65.7; H, 4.8. Calcd for $\mathrm{C}_{45} \mathrm{H}_{37} \mathrm{ClP}_{2} \mathrm{RuS} \cdot 0.25 \mathrm{CH}_{2} \mathrm{Cl}_{2}$ : C, 65.5; H, 4.6.

Preparation of $\left[\mathrm{Ru}\left(\mathrm{CH}=\mathbf{C H}_{2}\right) \mathbf{C l}(\mathrm{CS})\left(\mathrm{PPh}_{3}\right)_{2}\right]$ (3). [RuHCl$(\mathrm{CS})\left(\mathrm{PPh}_{3}\right)_{3}$ ] (400 mg, $\left.0.413 \mathrm{mmol}\right)$ was dissolved in dichloromethane $(40 \mathrm{~mL})$ and acetylene bubbled through the solution for $30 \mathrm{~s}$. After it was stirred under an atmosphere of acetylene for 40 min, the solution was diluted with ethanol $(25 \mathrm{~mL})$. Slow concentration provided orange crystals of the product, which were isolated by filtration, washed with ethanol $(2 \times 10 \mathrm{~mL})$ and light petroleum $(10 \mathrm{~mL})$, and dried under vacuum. Yield: $250 \mathrm{mg}(83 \%)$. IR (Nujol): 1586, 1567, 1548, $1269 v_{\mathrm{CS}}, 1230,1208,1186,969$, 868, $852 \mathrm{~cm}^{-1} .{ }^{1} \mathrm{H}$ NMR: $4.68\left(\mathrm{dd}, 1 \mathrm{H}, \mathrm{H}_{\beta}, J_{\mathrm{H}_{\beta} \mathrm{H}_{\alpha}}=14.2, J_{\mathrm{H}_{\beta} \mathrm{H}_{\beta}{ }^{\prime}}\right.$ $=1.7), 5.08\left(\mathrm{~m}, 1 \mathrm{H}, \mathrm{H}_{\beta^{\prime}}\right), 7.30-7.67\left(\mathrm{~m}, 31 \mathrm{H}, \mathrm{H}_{\alpha}\right.$ and $\left.\mathrm{C}_{6} \mathrm{H}_{5}\right)$ ppm. ${ }^{13} \mathrm{C}\left\{{ }^{1} \mathrm{H}\right\}$ NMR: $296.5\left(\mathrm{t}, \mathrm{CS}, J_{\mathrm{CP}}=15.2\right), 155.1(\mathrm{t}, \mathrm{RuCH}$, $\left.J_{\mathrm{CP}}=9.8\right), 134.6\left(\mathrm{t}^{\mathrm{v}}, o-/ m-\mathrm{PC}_{6} \mathrm{H}_{5}, J_{\mathrm{CP}}=5.4\right), 131.1\left(\mathrm{t}^{\mathrm{v}}, i-\mathrm{PC}_{6} \mathrm{H}_{5}\right.$, $\left.J_{\mathrm{CP}}=23.2\right), 130.2\left(\mathrm{~s}, p-\mathrm{PC}_{6} \mathrm{H}_{5}\right), 128.2\left(\mathrm{t}^{\mathrm{v}}, o-/ m-\mathrm{PC}_{6} \mathrm{H}_{5}, J_{\mathrm{CP}}=5.3\right)$, $119.0(\mathrm{~s}, \mathrm{RuC}=C)$ ppm. ${ }^{31} \mathrm{P}\left\{{ }^{1} \mathrm{H}\right\}$ NMR: $32.2 \mathrm{ppm}$. FAB-MS: $m / z$ (\% abundance) $697(10)[\mathrm{M}-\mathrm{Cl}]^{+}, 669(2)\left[\mathrm{M}-\right.$ alkenyl $^{+}, 443$ (5) $\left[\mathrm{M}-\mathrm{PPh}_{3}-\text { alkenyl }\right]^{+}, 407$ (4) $[\mathrm{M}-\mathrm{Cl}-\text { alkenyl }]^{+}$. Anal. Found: C, 63.9; H, 4.7. Calcd for $\mathrm{C}_{39} \mathrm{H}_{33} \mathrm{ClP}_{2} \mathrm{RuS}$ : C, 64.0; $\mathrm{H}$, 4.5.

Preparation of $\left[\mathrm{Ru}\{\mathrm{C}(\mathrm{C} \equiv \mathrm{CPh})=\mathrm{CHPh}\} \mathrm{Cl}(\mathrm{CS})\left(\mathrm{PPh}_{3}\right)_{2}\right]$ (4). $\left[\mathrm{RuHCl}(\mathrm{CS})\left(\mathrm{PPh}_{3}\right)_{3}\right](300 \mathrm{mg}, 0.310 \mathrm{mmol})$ and 1,4-diphenylbuta1,3-diyne (130 mg, $0.64 \mathrm{mmol}$ ) were suspended in tetrahydrofuran $(20 \mathrm{~mL})$ and heated under reflux for $10 \mathrm{~min}$. The solution was cooled and diluted with ethanol $(30 \mathrm{~mL})$. Bright orange crystals of the product were obtained on concentration under reduced pressure and isolated by filtration. These were washed with ethanol $(2 \times$ $10 \mathrm{~mL})$ and light petroleum $(10 \mathrm{~mL})$ and dried under vacuum. Yield: $230 \mathrm{mg}(82 \%)$. IR (Nujol): 1719, 1586, 1570, $1279 v_{\mathrm{CS}}$, 955, 914, $845 \mathrm{~cm}^{-1} .{ }^{1} \mathrm{H}$ NMR: $5.50\left(\mathrm{t}, 1 \mathrm{H},=\mathrm{C}_{\beta} \mathrm{H}, J_{\mathrm{HP}}=1.7\right)$, 7.09, 7.07, $7.06\left(\mathrm{~m} \times 3, \mathrm{CC}_{6} \mathrm{H}_{5}\right), 7.15-7.75\left(\mathrm{~m}, 30 \mathrm{H}, \mathrm{PC}_{6} \mathrm{H}_{5}\right)$ ppm. ${ }^{13} \mathrm{C}\left\{{ }^{1} \mathrm{H}\right\}$ NMR: $300.5\left(\mathrm{t}, \mathrm{CS}, J_{\mathrm{CP}}=16.1\right), 142.8\left(\mathrm{t}, \mathrm{RuC}, J_{\mathrm{CP}}\right.$ $=8.0), 138.4(\mathrm{RuC}=C), 135.0\left(\mathrm{t}^{\mathrm{v}}, o-/ m-\mathrm{PC}_{6} \mathrm{H}_{5}, J_{\mathrm{CP}}=5.4\right), 130.6$ $\left(\mathrm{t}^{\mathrm{v}}, i-\mathrm{PC}_{6} \mathrm{H}_{5}, J_{\mathrm{CP}}=22.3\right), 130.0\left(p-\mathrm{PC}_{6} \mathrm{H}_{5}\right), 128.3\left(\mathrm{C}_{6} \mathrm{H}_{5}\right), 127.8$ ( $\mathrm{t}^{\mathrm{v}}, o-/ m-\mathrm{PC}_{6} \mathrm{H}_{5}, J_{\mathrm{CP}}$ unresolved), 126.2, $125.5\left(\mathrm{~s} \times 2, \mathrm{C}_{6} \mathrm{H}_{5}\right), 123.8$, $120.1(\mathrm{~s} \times 2, \mathrm{C} \equiv \mathrm{C}) \mathrm{ppm} .{ }^{31} \mathrm{P}\left\{{ }^{1} \mathrm{H}\right\}$ NMR: $33.1 \mathrm{ppm}$. FAB-MS: $m / z$ (\% abundance) $908(66)[\mathrm{M}]^{+}, 873(97)[\mathrm{M}-\mathrm{Cl}]^{+}, 705(23)$ $[\mathrm{M}-\text { alkenyl }]^{+}, 669(10)\left[\mathrm{M}-\mathrm{Cl}-\right.$ alkenyl $^{+}, 646(10)[\mathrm{M}-$
$\left.\mathrm{PPh}_{3}\right]^{+}, 611(100)\left[\mathrm{M}-\mathrm{PPh}_{3}\right]+, 407(60)\left[\mathrm{Ru}(\mathrm{CS}) \mathrm{PPh}_{3}\right]^{+}, 363$ (14) $\left[\mathrm{RuPPh}_{3}\right]^{+}$Anal. Found: $\mathrm{C}, 67.6 ; \mathrm{H}, 4.8$. Calcd for $\mathrm{C}_{53} \mathrm{H}_{41^{-}}$ $\mathrm{ClP}_{2} \mathrm{RuS} \cdot 0.5 \mathrm{CH}_{2} \mathrm{Cl}_{2}$ : C, 67.6; $\mathrm{H}, 4.5$.

Preparation of $\left[\mathrm{Ru}\left\{\mathrm{C}\left(\mathrm{CO}_{2} \mathrm{Me}\right)=\mathrm{CHCO}_{2} \mathrm{Me}\right\} \mathrm{Cl}(\mathrm{CS})\left(\mathrm{PPh}_{3}\right)_{2}\right]$ (5). A solution of $\left[\mathrm{RuHCl}(\mathrm{CS})\left(\mathrm{PPh}_{3}\right)_{3}\right](200 \mathrm{mg}, 0.207 \mathrm{mmol})$ in dichloromethane $(10 \mathrm{~mL})$ was treated with dimethyl acetylenedicarboxylate $(0.15 \mathrm{~mL}, 1.217 \mathrm{mmol})$ and stirred for $10 \mathrm{~min}$. The yellow solution was diluted with ethanol $(20 \mathrm{~mL})$ and concentrated under reduced pressure to provide yellow crystals of the product. These were isolated by filtration, washed with ethanol $(2 \times 10$ $\mathrm{mL})$ and light petroleum $(10 \mathrm{~mL})$, and dried under vacuum. Yield: $150 \mathrm{mg}(85 \%)$. The product can be recrystallized from chloroformethanol mixtures. IR (Nujol): 1722, $1693 v_{\mathrm{C}=\mathrm{O}}, 1600,1573,1336$, $1284 v_{\mathrm{CS}}, 1223,1006,916,1256,889,853 \mathrm{~cm}^{-1} .{ }^{1} \mathrm{H}$ NMR: 2.89 $\left(\mathrm{s}, 3 \mathrm{H}, \mathrm{CH}_{3}\right), 3.54\left(\mathrm{~s}, 3 \mathrm{H}, \mathrm{CH}_{3}\right), 4.98\left(\mathrm{t}, 1 \mathrm{H},=\mathrm{CH}, J_{\mathrm{HP}}=1.5\right.$ $\mathrm{Hz}), 7.25-7.80\left(\mathrm{~m}, 30 \mathrm{H}, \mathrm{C}_{6} \mathrm{H}_{5}\right) \mathrm{ppm} .{ }^{31} \mathrm{P}\left\{{ }^{1} \mathrm{H}\right\}$ NMR: $32.6 \mathrm{ppm}$. FAB-MS: not diagnostic. Anal. Found: $\mathrm{C}, 57.4 ; \mathrm{H}, 3.7$. Calcd for $\mathrm{C}_{43} \mathrm{H}_{37} \mathrm{ClO}_{4} \mathrm{P}_{2} \mathrm{RuS} \cdot 0.5 \mathrm{CHCl}_{3}$ : C, 57.5; H, 4.2.

Preparation of $\left[\mathrm{Ru}\left(\mathrm{CH}=\mathrm{CH}_{2}\right) \mathrm{Cl}(\mathrm{CS})(\mathrm{BSD})\left(\mathrm{PPh}_{3}\right)_{2}\right](6)$. [Ru$\left.\left(\mathrm{CH}=\mathrm{CH}_{2}\right) \mathrm{Cl}(\mathrm{CS})\left(\mathrm{PPh}_{3}\right)_{2}\right](3 ; 180 \mathrm{mg}, 0.246 \mathrm{mmol})$ was dissolved in dichloromethane $(5 \mathrm{~mL})$ and 2,1,3-benzoselenadiazole $(60 \mathrm{mg}$, $0.328 \mathrm{mmol})$ added. Ethanol $(10 \mathrm{~mL})$ was then added and the mixture stirred for $30 \mathrm{~min}$, during which time a yellow solid precipitated from solution. This was filtered off, washed with ethanol $(10 \mathrm{~mL})$ and hexane $(10 \mathrm{~mL})$, and dried under vacuum. Yield: $180 \mathrm{mg}(80 \%)$. IR (Nujol): 1585, 1560, 1513, 1313, 1271 $v_{\mathrm{CS}}, 1236,1136,1116,917,889,843,814 \mathrm{~cm}^{-1}$. ${ }^{1} \mathrm{H}$ NMR: 5.06 $\left(\mathrm{d}, 1 \mathrm{H}, \mathrm{H}_{\beta}, J_{\mathrm{H}_{\alpha} \mathrm{H}_{\beta}}=16.8\right), 5.59\left(\mathrm{~d}, 1 \mathrm{H}, \mathrm{H}_{\beta^{\prime}}, J_{\mathrm{H}_{\alpha} \mathrm{H}_{\beta^{\prime}}}=8.6\right), 7.11-$ $7.57\left(\mathrm{~m}, 34 \mathrm{H}, \mathrm{C}_{6} \mathrm{H}_{5}+\mathrm{C}_{6} \mathrm{H}_{4} \mathrm{~N}_{2} \mathrm{Se}\right), 8.18\left(\mathrm{~m}, 1 \mathrm{H}, \mathrm{H}_{\alpha}\right)$ ppm. ${ }^{31} \mathrm{P}\left\{{ }^{1} \mathrm{H}\right\}$ NMR: $26.1 \mathrm{ppm}$. FAB-MS: $m / z$ (\% abundance) $863(4)$ $\left[\mathrm{M}-\mathrm{C}_{4} \mathrm{H}_{4}\right]^{+}, 836(2)\left[\mathrm{M}-\mathrm{SCCHCH}_{2}\right]^{+} .697$ (5) [M - BSD $\mathrm{Cl}]^{+}, 669$ (4) $[\mathrm{M}-\text { alkenyl }-\mathrm{Cl}-\mathrm{BSD}]^{+}, 433$ (3) [HM - BSD $\left.-\mathrm{PPh}_{3}-\mathrm{Cl}\right]^{+}, 407$ (7) $\left[\mathrm{Ru}(\mathrm{CS})\left(\mathrm{PPh}_{3}\right)\right]^{+}, 263(25)\left[\mathrm{HPPh}_{3}\right]^{+}$. Anal. Found: C, 58.9; H, 4.1; N, 3.0. Calcd for $\mathrm{C}_{45} \mathrm{H}_{37} \mathrm{ClN}_{2} \mathrm{P}_{2}$ RuSSe: C, 59.1; H, 4.1; N, 3.1.

Preparation of $\left[\mathrm{RuHCl}(\mathrm{CS})(\mathrm{BSD})\left(\mathrm{PPh}_{3}\right)_{2}\right]$ (7). A suspension of $\left[\mathrm{RuHCl}(\mathrm{CS})\left(\mathrm{PPh}_{3}\right)_{3}\right](310 \mathrm{mg}, 0.320 \mathrm{mmol})$ in tetrahydrofuran $(30 \mathrm{~mL})$ was treated with 2,1,3-benzoselenadiazole $(120 \mathrm{mg}, 0.656$ $\mathrm{mmol})$. The mixture was heated under reflux for $1 \mathrm{~h}$ and then cooled and diluted with ethanol $(30 \mathrm{~mL})$. The solvent volume was reduced slowly, resulting in the formation of olive green crystals. These were filtered off, washed with ethanol $(20 \mathrm{~mL})$ and hexane $(20$ $\mathrm{mL}$ ), and dried under vacuum. Yield: $270 \mathrm{mg}$ (95\%). IR (Nujol): 2052, $2027 v_{\mathrm{RuH}}, 1716,1585,1570,1266 v_{\mathrm{CS}} \mathrm{cm}^{-1} .{ }^{1} \mathrm{H}$ NMR: $-10.46\left(\mathrm{t}, 1 \mathrm{H}, \mathrm{RuH}, J_{\mathrm{HP}}=19.3\right), 6.87-7.68\left(\mathrm{~m}, 34 \mathrm{H}, \mathrm{C}_{6} \mathrm{H}_{5}+\right.$ $\mathrm{C}_{6} \mathrm{H}_{4}$ ) ppm. ${ }^{31} \mathrm{P}\left\{{ }^{1} \mathrm{H}\right\}$ NMR: 43.6 ppm. FAB-MS: $\mathrm{m} / \mathrm{z}$ (\% abundance) 836 (2) $\left[\mathrm{M}-\mathrm{C}_{4} \mathrm{H}_{4}\right]^{+}, 705$ (2) $\left[\mathrm{M}-\mathrm{H}-\mathrm{BSD}^{+}, 669\right.$ (2) $\left[\mathrm{M}-\mathrm{H}-\mathrm{Cl}-\mathrm{BSD}^{+}\right.$. Anal. Found: $\mathrm{C}, 58.0 ; \mathrm{H}, 4.0 ; \mathrm{N}, 2.9$. Calcd for $\mathrm{C}_{43} \mathrm{H}_{35} \mathrm{ClN}_{2} \mathrm{P}_{2}$ RuSSe: C, 58.1; H, 4.0; N, 3.2.

Preparation of the Complexes $\left[\mathrm{Ru}\left(\eta^{2}-\mathrm{SCCR}^{1}=\mathrm{CHR}^{2}\right) \mathrm{Cl}(\mathrm{CO})\right.$ $\left.\left(\mathbf{P P h}_{3}\right)_{2}\right]\left(\mathbf{R}^{1}=\mathbf{R}^{2}=\mathbf{H}, \mathbf{P h} ; \mathbf{R}^{1}=\mathbf{H}, \mathbf{R}^{2}=\mathbf{P h} ; \mathbf{R}^{1}=\mathbf{C} \equiv \mathbf{C P h}\right.$, $\left.\mathbf{R}^{2}=\mathrm{Ph}\right)$ and $\left[\mathrm{Ru}\left\{\mathrm{C}\left(\mathrm{CO}_{2} \mathrm{Me}\right)=\mathrm{CHCO}_{2} \mathrm{Me}\right\} \mathrm{Cl}(\mathrm{CO})(\mathrm{CS})\left(\mathrm{PPh}_{3}\right)_{2}\right]$. A stream of carbon monoxide was passed through a solution of the respective complex $\left[\mathrm{Ru}\left(\mathrm{CR}^{1}=\mathrm{CHR}^{2}\right) \mathrm{Cl}(\mathrm{CS})\left(\mathrm{PPh}_{3}\right)_{2}\right](\mathbf{1}-\mathbf{4})$ or $\left[\mathrm{Ru}\left\{\mathrm{C}\left(\mathrm{CO}_{2} \mathrm{Me}\right)=\mathrm{CHCO}_{2} \mathrm{Me}\right\} \mathrm{Cl}(\mathrm{CS})\left(\mathrm{PPh}_{3}\right)_{2}\right](\mathbf{5})(0.20 \mathrm{mmol})$ in dichloromethane $(10 \mathrm{~mL})$ for $10 \mathrm{~s}$ and then the mixture stirred for $5 \mathrm{~min}$. The solution was diluted with ethanol $(40 \mathrm{~mL})$ and stirred for a further $10 \mathrm{~min}$. The resulting crystals of the product were isolated by filtration, washed with ethanol $(2 \times 10 \mathrm{~mL})$ and light petroleum $(10 \mathrm{~mL})$, and dried under vacuum. Yield: spectroscopically quantitative $\left({ }^{31} \mathrm{P} \mathrm{NMR}\right)$.

$\left[\mathbf{R u}\left(\eta^{2}-\mathbf{S C C P h}=\mathbf{C H P h}\right) \mathbf{C l}(\mathbf{C O})\left(\mathbf{P P h}_{3}\right)_{2}\right](\mathbf{8}) . \mathrm{IR}\left(\mathrm{CH}_{2} \mathrm{Cl}_{2}\right): 1913$ $v_{\mathrm{CO}}, 1602,1584,1572,1563 \mathrm{~cm}^{-1}$. IR (Nujol): $1915 v_{\mathrm{CO}}, 1582$, $1562,1312,1256,1205,1155,1144,951,939,915,889,845,818$ $\mathrm{cm}^{-1} .{ }^{1} \mathrm{H}$ NMR: $5.99\left(\mathrm{~d}, 2 \mathrm{H}, \mathrm{C}^{2,6}\left(\mathrm{C}_{6} \mathrm{H}_{5}\right), J_{\mathrm{HH}}=7.3\right), 6.75(\mathrm{~d}, 2$ $\left.\mathrm{H}, \mathrm{H}^{2,6}\left(\mathrm{C}_{6} \mathrm{H}_{5}\right), J_{\mathrm{HH}}=7.6\right), 7.14\left(\mathrm{~m}, \mathrm{H}^{3,5}\left(\mathrm{C}_{6} \mathrm{H}_{5}\right)\right), 7.38(\mathrm{~s}, 1 \mathrm{H}$, $\mathrm{CHPh}), 7.28-7.77\left(\mathrm{~m}, 30 \mathrm{H}, \mathrm{PC}_{6} \mathrm{H}_{5}\right) \mathrm{ppm} .{ }^{13} \mathrm{C}\left\{{ }^{1} \mathrm{H}\right\}$ NMR: 306.0 
$\left(\mathrm{t}, \mathrm{CS}, J_{\mathrm{CP}}=8.9\right), 210.2\left(\mathrm{t}, \mathrm{CO}, J_{\mathrm{CP}}=15.2\right), 154.6,152.3,144.2$ $\left(\mathrm{CC}_{6} \mathrm{H}_{5}\right.$ and $\left.=\mathrm{CHPh}\right), 140.1-126.0 \mathrm{ppm}\left(\mathrm{m}, \mathrm{PC}_{6} \mathrm{H}_{5}+\mathrm{CC}_{6} \mathrm{H}_{5}\right.$, individual assignments equivocal). ${ }^{31} \mathrm{P}\left\{{ }^{1} \mathrm{H}\right\}$ NMR: $30.2 \mathrm{ppm}$. FABMS: $m / z$ (\% abundance) $912(3)[\mathrm{M}]^{+}, 884(83)[\mathrm{M}-\mathrm{CO}]^{+}, 877$ (100) $[\mathrm{M}-\mathrm{Cl}]^{+}, 849$ (2) $[\mathrm{M}-\mathrm{Cl}-\mathrm{CO}]^{+}, 689$ (20) $[\mathrm{M}-$ $\mathrm{SCCPh}=\mathrm{CHPh}]^{+}, 622(22)\left[\mathrm{M}-\mathrm{CO}-\mathrm{PPh}_{3}\right]^{+}, 615(18)[\mathrm{M}-$ $\left.\mathrm{Cl}-\mathrm{PPh}_{3}\right]^{+}, 586$ (79) $\left[\mathrm{M}-\mathrm{Cl}-\mathrm{CO}-\mathrm{PPh}_{3}\right]^{+}, 363$ (24) $\left[\mathrm{RuPPh}_{3}\right]^{+}, 324(27)\left[\mathrm{M}-\mathrm{Cl}-\mathrm{CO}-2 \mathrm{PPh}_{3}\right]^{+}$. Anal. Found: $\mathrm{C}$, 64.1; H, 3.4. Calcd for $\mathrm{C}_{52} \mathrm{H}_{41} \mathrm{ClOP}_{2} \mathrm{RuS} \cdot \mathrm{CH}_{2} \mathrm{Cl}_{2}$ : C, 63.8; $\mathrm{H}, 4.4$.

$\left[\mathbf{R u}\left(\eta^{2} \mathbf{- S C C H}=\mathbf{C H P h}\right) \mathbf{C l}(\mathbf{C O})\left(\mathbf{P P h}_{3}\right)_{2}\right](\mathbf{9}) . \mathrm{IR}\left(\mathrm{CH}_{2} \mathrm{Cl}_{2}\right): 1919$ $v_{\mathrm{CO}}, 1711,1604,1594,1571 \mathrm{~cm}^{-1}$. IR (Nujol): $1911 v_{\mathrm{CO}}, 1716$, $1616,1592,1571,1332,1293,1264,1194,966,927,881,790 \mathrm{~cm}^{-1}$. ${ }^{1} \mathrm{H}$ NMR: $6.33\left(\mathrm{~d}, 1 \mathrm{H}, \mathrm{H}_{\beta}, J_{\mathrm{H}_{\alpha} \mathrm{H}_{\beta}}=14.8\right), 6.55\left(\mathrm{~d}, 1 \mathrm{H}, \mathrm{H}_{\alpha}, J_{\mathrm{H}_{\alpha} \mathrm{H}_{\beta}}\right.$ $=14.8), 7.03\left(\mathrm{~d}, 2 \mathrm{H}, \mathrm{C}^{2,6}\left(\mathrm{C}_{6} \mathrm{H}_{5}\right), J_{\mathrm{HH}}=7.3\right), 7.36(\mathrm{t}, 2 \mathrm{H}$, $\left.\mathrm{C}^{3,5}\left(\mathrm{C}_{6} \mathrm{H}_{5}\right), J_{\mathrm{HH}}=7.6\right), 7.18-7.85\left(\mathrm{~m}, 31 \mathrm{H}, \mathrm{PC}_{6} \mathrm{H}_{5}\right.$ and $\left.\mathrm{C}_{4}\left(\mathrm{CC}_{6} \mathrm{H}_{5}\right)\right)$ ppm. ${ }^{31} \mathrm{P}\left\{{ }^{1} \mathrm{H}\right\}$ NMR: $29.2 \mathrm{ppm}$. FAB-MS: $m / z$ (abundance) 836 (4) $[\mathrm{M}]^{+}, 808$ (41) $[\mathrm{M}-\mathrm{CO}]^{+}, 801$ (57) $[\mathrm{M}-\mathrm{Cl}]^{+}, 689$ (3) $[\mathrm{M}$ $-\mathrm{SCCH}=\mathrm{CHPh}]^{+}, 546(15)\left[\mathrm{M}-\mathrm{CO}-\mathrm{PPh}_{3}\right]^{+}, 511(11)[\mathrm{M}-$ $\left.\mathrm{Cl}-\mathrm{CO}-\mathrm{PPh}_{3}\right]^{+}, 363(8)\left[\mathrm{RuPPh}_{3}\right]^{+}$. Anal. Found: C, 64.6; H, 4.0. Calcd for $\mathrm{C}_{46} \mathrm{H}_{37} \mathrm{ClOP}_{2} \mathrm{RuS} \cdot 0.25 \mathrm{CH}_{2} \mathrm{Cl}_{2}$ : C, 64.8; H, 4.4. [Ru$\left.\left.\left(\eta^{2}-\mathbf{S C C H}=\mathbf{C H}\right) \mathbf{C l}(\mathbf{C O})\left(\mathbf{P P h}_{3}\right)_{2}\right] \mathbf{( 1 0}\right)$. IR $\left(\mathrm{CH}_{2} \mathrm{Cl}_{2}\right): 1921 v_{\mathrm{CO}}$ $\mathrm{cm}^{-1}$. IR (Nujol): 1930, $1913 v_{\mathrm{CO}}, 1717,1616,1588,1572,1306$, 1289, 1237, 1192, 965, 892, $832 \mathrm{~cm}^{-1}$. ${ }^{1} \mathrm{H}$ NMR: $4.71(\mathrm{dd}, 1 \mathrm{H}$, $\left.\mathrm{H}_{\beta^{\prime}}, J_{\mathrm{H}_{\alpha} \mathrm{H}_{\beta}}{ }^{\prime}=9.9, J_{\mathrm{H}_{\alpha} \mathrm{H}_{\beta}}=1.0\right), 5.23\left(\mathrm{dd}, 1 \mathrm{H}, \mathrm{H} \beta, J_{\mathrm{H}_{\alpha} \mathrm{H}_{\beta}}=16.8\right.$, $\left.J_{\mathrm{H}_{\beta} \mathrm{H}_{\beta}},=1.0\right), 6.03\left(\mathrm{ddd}, 1 \mathrm{H}, \mathrm{H} \alpha, J_{\mathrm{H}_{\alpha} \mathrm{H}_{\beta}}=9.7, J_{\mathrm{H}_{\alpha} \mathrm{H}_{\beta}}=16.7\right)$, 7.35, $7.78\left(\mathrm{~m} \times 2,30 \mathrm{H}, \mathrm{C}_{6} \mathrm{H}_{5}\right)$ ppm. ${ }^{31} \mathrm{P}\left\{{ }^{1} \mathrm{H}\right\}$ NMR: $29.1 \mathrm{ppm}$. FAB-MS: $m / z(\%$ abundance $) 760(3)[\mathrm{M}]^{+}, 732(46)[\mathrm{M}-\mathrm{CO}]^{+}$, $725(52)[\mathrm{M}-\mathrm{Cl}]^{+}, 689(58)\left[\mathrm{M}-\mathrm{SCCH}=\mathrm{CH}_{2}\right]^{+}, 654$ (2) $[\mathrm{M}-$ $\left.\mathrm{Cl}-\mathrm{SCCH}=\mathrm{CH}_{2}\right]^{+}, 625(3)\left[\mathrm{M}-\mathrm{Cl}-\mathrm{CO}-\mathrm{SCCH}=\mathrm{CH}_{2}\right]^{+}$, 470 (6) $\left[\mathrm{M}-\mathrm{CO}-\mathrm{PPh}_{3}\right]^{+}, 435$ (7) $\left[\mathrm{M}-\mathrm{Cl}-\mathrm{CO}-\mathrm{PPh}_{3}\right]^{+}$. Anal. Found: C, 58.5; H, 4.3. Calcd for $\mathrm{C}_{40} \mathrm{H}_{33} \mathrm{ClOP}_{2} \mathrm{RuS}$. $\mathrm{CH}_{2} \mathrm{Cl}_{2}$ : C, 58.3; $\mathrm{H}, 4.2$.

$\left[\mathbf{R u}\left\{\eta^{2}-\mathrm{SCC}(\mathbf{C} \equiv \mathbf{C P h})=\mathbf{C H P h}\right\} \mathbf{C l}(\mathbf{C O})\left(\mathbf{P P h}_{3}\right)_{2}\right] \quad$ (11). IR $\left(\mathrm{CH}_{2} \mathrm{Cl}_{2}\right): 1916 \mathrm{~cm}^{-1}$. IR (Nujol): $2193 v_{\mathrm{C} \equiv \mathrm{C}}, 1909 v_{\mathrm{CO}}, 1595$, $1579,1555,1324,1258,1193,1180,928,920,870,843,819 \mathrm{~cm}^{-1}$. ${ }^{1} \mathrm{H}$ NMR: $6.80(\mathrm{~s}, 1 \mathrm{H}, \mathrm{C}=\mathrm{CH}), 7.20-7.90\left(\mathrm{~m}, 40 \mathrm{H}, \mathrm{C}_{6} \mathrm{H}_{5}\right) \mathrm{ppm}$. ${ }^{13} \mathrm{C}\left\{{ }^{1} \mathrm{H}\right\}$ NMR: 304.8 (t, CS, $J_{\mathrm{CP}}$ not resolved), 209.4 (t, CO, $J_{\mathrm{CP}}$ not resolved $), 154.5(C \mathrm{C} \equiv \mathrm{C}), 138.0-125.0\left(\mathrm{C}_{6} \mathrm{H}_{5}\right.$, individual assignments equivocal), 123.2, $95.4(\mathrm{C} \equiv \mathrm{C}) \mathrm{ppm} .{ }^{31} \mathrm{P}\left\{{ }^{1} \mathrm{H}\right\} \mathrm{NMR}$ : 29.4 ppm. FAB-MS: $m / z$ (\% abundance) $936(2)[\mathrm{M}]^{+}, 908$ (53) $\left[\mathrm{M}-\mathrm{CO}^{+}, 901(100)[\mathrm{M}-\mathrm{Cl}]^{+}, 689(6)\left[\mathrm{RuCl}(\mathrm{CO})\left(\mathrm{PPh}_{3}\right)_{2}\right]^{+}\right.$, $646(10)\left[\mathrm{M}-\mathrm{CO}-\mathrm{PPh}_{3}\right]^{+}, 625(10)\left[\mathrm{Ru}\left(\mathrm{PPh}_{3}\right)_{2}\right]^{+}, 611(82)[\mathrm{M}$ $\left.-\mathrm{Cl}-\mathrm{CO}-\mathrm{PPh}_{3}\right]^{+}, 533(10)\left[\mathrm{M}-\mathrm{Cl}-\mathrm{CO}-\mathrm{Ph}-\mathrm{PPh}_{3}\right]^{+}$, 363 (18) $\left[\mathrm{RuPPh}_{3}\right]^{+}, 263(72)\left[\mathrm{HPPh}_{3}\right]^{+}$. Anal. Found: C, 65.6; $\mathrm{H}$, 4.8. Calcd for $\mathrm{C}_{54} \mathrm{H}_{41} \mathrm{ClOP}_{2} \mathrm{RuS} \cdot 0.75 \mathrm{CH}_{2} \mathrm{Cl}_{2}$ : C, 65.8; $\mathrm{H}, 4.3$.

$\left[\mathbf{R u}\left\{\mathbf{C}\left(\mathrm{CO}_{2} \mathrm{Me}\right)=\mathrm{CHCO}_{2} \mathrm{Me}\right\} \mathrm{Cl}(\mathrm{CO})(\mathrm{CS})\left(\mathrm{PPh}_{3}\right)_{2}\right] \quad$ (12). IR $\left(\mathrm{CH}_{2} \mathrm{Cl}_{2}\right): 2029 v_{\mathrm{CO}}, 1706 v_{\mathrm{C}=\mathrm{O}}, 1604 v_{\mathrm{C}=\mathrm{O}} \mathrm{cm}^{-1}$. IR (Nujol): 2009 $v_{\mathrm{CO}}, 1703 v_{\mathrm{C}=\mathrm{O}}, 1693 v_{\mathrm{C}=\mathrm{O}}, 1583,1574,1319 v_{\mathrm{CS}}, 1213,1187$, 1161, 890, 868, $825 \mathrm{~cm}^{-1} .{ }^{1} \mathrm{H}$ NMR: $3.31\left(\mathrm{~s}, 3 \mathrm{H}, \mathrm{CH}_{3}\right), 3.49$ (s, $\left.3 \mathrm{H}, \mathrm{CH}_{3}\right), 5.28\left(\mathrm{t}, 1 \mathrm{H},=\mathrm{CHR}, J_{\mathrm{HP}}=2.1\right), 7.26-7.79(\mathrm{~m}, 30 \mathrm{H}$, $\left.\mathrm{C}_{6} \mathrm{H}_{5}\right)$ ppm. ${ }^{31} \mathrm{P}\left\{{ }^{1} \mathrm{H}\right\}$ NMR: 27.7 ppm. FAB-MS: $m / z$ (\% abundance) $877(2)[\mathrm{M}]^{+}, 845(20)[\mathrm{M}-\mathrm{Cl}]^{+}, 813(38)[\mathrm{M}-\mathrm{Cl}-$ $\mathrm{CO}]^{+}, 705$ (15) $[\mathrm{M}-\mathrm{CO}-\mathrm{CR}=\mathrm{CHR}]^{+}, 689$ (7) $[\mathrm{RuCl}(\mathrm{CO})-$ $\left.\left(\mathrm{PPh}_{3}\right)_{2}\right]^{+}, 670(7)\left[\mathrm{Ru}(\mathrm{CS})\left(\mathrm{PPh}_{3}\right)_{2}\right]^{+}, 586(7)\left[\mathrm{M}-\mathrm{CO}-\mathrm{PPh}_{3}\right]^{+}$, $551(15)\left[\mathrm{M}-\mathrm{Cl}-\mathrm{CO}-\mathrm{PPh}_{3}\right]^{+}, 407$ (22) $\left[\mathrm{Ru}(\mathrm{CS}) \mathrm{PPh}_{3}\right]^{+}, 363$ (4) $\left[\mathrm{RuPPh}_{3}\right]^{+}$. Anal. Found: C, 56.6; H, 3.7. Calcd for $\mathrm{C}_{44} \mathrm{H}_{37^{-}}$ $\mathrm{ClO}_{5} \mathrm{P}_{2} \mathrm{RuS} \cdot \mathrm{CH}_{2} \mathrm{Cl}_{2}: \mathrm{C}, 56.2 ; \mathrm{H}, 4.1$.

Preparation of $\left[\left(\mathrm{PPh}_{3}\right)_{2}(\mathrm{CO}) \mathrm{ClRu}\left(\eta^{2}-\mathrm{SCCH}=\mathrm{CHC}_{6} \mathrm{H}_{4} \mathrm{CH}=\right.\right.$ CHCS- $\left.\left.\eta^{2}\right) \mathbf{R u C l}(\mathbf{C O})\left(\mathbf{P P h}_{3}\right)_{2}\right]_{2}$ (13). $\left[\mathrm{RuHCl}(\mathrm{CS})\left(\mathrm{PPh}_{3}\right)_{3}\right]$ (300 mg, $0.310 \mathrm{mmol})$ and 1,4-diethynylbenzene (20 $\mathrm{mg}, 0.159 \mathrm{mmol})$ were dissolved in dichloromethane $(20 \mathrm{~mL})$, prompting a color change to purple after $30 \mathrm{~min}$ of stirring. Ethanol $(15 \mathrm{~mL})$ was added and carbon monoxide passed through the solution for $20 \mathrm{~s}$. The flask was stoppered and stirred and the addition repeated. After 30 min of stirring, a brown solid was filtered, and on washing with diethyl ether $(30 \mathrm{~mL})$, this became dark brick red and was further washed with ethanol $(10 \mathrm{~mL})$ and hexane $(10 \mathrm{~mL})$ and dried. Yield: 280 mg (57\%). IR $\left(\mathrm{CH}_{2} \mathrm{Cl}_{2}\right): 1918 v_{\mathrm{CO}}, 1589 \mathrm{~cm}^{-1}$. IR (Nujol): 1906 $v_{\mathrm{CO}}, 1719,1584,1547,1324,1238,961,936,888,846,815 \mathrm{~cm}^{-1}$. ${ }^{1} \mathrm{H}$ NMR: $6.43,6.53\left(\mathrm{AB}, 4 \mathrm{H}, \mathrm{CH}=\mathrm{CH}, J_{\mathrm{AB}}=15.5\right), 6.98(\mathrm{~s}, 4$ $\left.\mathrm{H}, \mathrm{C}_{6} \mathrm{H}_{4}\right), 7.28-7.83\left(\mathrm{~m}, 30 \mathrm{H}, \mathrm{PC}_{6} \mathrm{H}_{5}\right)$ ppm. ${ }^{13} \mathrm{C}\left\{{ }^{1} \mathrm{H}\right\}$ NMR: not sufficiently soluble. ${ }^{31} \mathrm{P}\left\{{ }^{1} \mathrm{H}\right\}$ NMR: $29.5 \mathrm{ppm}$. FAB-MS: $\mathrm{m} / z(\%$ abundance) 1566 (47) $[\mathrm{M}-\mathrm{CO}]^{+}, 1301(100)\left[\mathrm{M}-\mathrm{CO}-\mathrm{PPh}_{3}\right]^{+}$, 1267 (31) $\left[\mathrm{M}-\mathrm{Cl}-\mathrm{PPh}_{3}\right]^{+}$. Anal. Found: C, 63.3; H, 4.2. Calcd for $\mathrm{C}_{86} \mathrm{H}_{68} \mathrm{Cl}_{2} \mathrm{O}_{2} \mathrm{P}_{4} \mathrm{Ru}_{2} \mathrm{~S}_{2} \cdot 0.5 \mathrm{CH}_{2} \mathrm{Cl}_{2}$ : C, 63.5; $\mathrm{H}, 4.3$.

Preparation of $\left[\mathrm{Ru}\left(\mathrm{CH}=\mathrm{CH}_{2}\right)\left(\kappa^{2}-\mathrm{O}_{2} \mathrm{CH}\right)(\mathrm{CS})\left(\mathrm{PPh}_{3}\right)_{2}\right]$ (14). $\left[\mathrm{Ru}\left(\mathrm{CH}=\mathrm{CH}_{2}\right) \mathrm{Cl}(\mathrm{CS})\left(\mathrm{PPh}_{3}\right)_{2}\right](\mathbf{3} ; 90 \mathrm{mg}, 0.123 \mathrm{mmol})$ was dissolved in dichloromethane $(15 \mathrm{~mL})$, and ethanol $(10 \mathrm{~mL})$ was added. $\mathrm{Na}\left[\mathrm{O}_{2} \mathrm{CH}\right](20 \mathrm{mg}, 0.294 \mathrm{mmol})$ was added as a water $(1 \mathrm{~mL})-$ ethanol $(5 \mathrm{~mL})$ solution. This prompted an instant color change of solution to yellow. After the mixture was stirred for $15 \mathrm{~min}$, all solvent was removed, the crude product was dissolved in dichloromethane $(10 \mathrm{~mL})$, and this solution was filtered through diatomaceous earth to remove $\mathrm{NaCl}$. Ethanol $(10 \mathrm{~mL})$ was added, and pale yellow crystals of the product precipitated by rotary evaporation. These were filtered, washed with ethanol $(10 \mathrm{~mL})$ and petroleum ether $(10 \mathrm{~mL})$, and dried. Yield: $70 \mathrm{mg}(77 \%)$. IR $\left(\mathrm{CH}_{2} \mathrm{Cl}_{2}\right)$ : $1605,1548 v_{\mathrm{OCO}} \mathrm{cm}^{-1}$. IR (Nujol): 1962, 1914, 1816, 1718, 1628 , $1615,1587,1571,1547 v_{\mathrm{OCO}}, 1334,1312,1274 v_{\mathrm{CS}}, 1238,868$, $800 \mathrm{~cm}^{-1} .{ }^{1} \mathrm{H}$ NMR: $4.84\left(\mathrm{dt}, 1 \mathrm{H}, \mathrm{H}_{\beta}, J_{\mathrm{H}_{\alpha} \mathrm{H}_{\beta}}=16.2, J_{\mathrm{H}_{\beta} \mathrm{Hp}_{\mathrm{p}}}=1.7\right)$, $5.01\left(\mathrm{dt}, 1 \mathrm{H}, \mathrm{H}_{\beta^{\prime}}, J_{\mathrm{H}_{\alpha} \mathrm{H}_{\beta^{\prime}}}=9.2, J_{\mathrm{H}^{\prime} \mathrm{H}_{\mathrm{P}}}=2.1\right), 7.00\left(\mathrm{t}, 1 \mathrm{H}, \mathrm{O}_{2} \mathrm{CH}\right.$, $\left.J_{\mathrm{HP}}=1.8\right), 7.35-7.58\left(\mathrm{~m}, 1 \mathrm{H}+30 \mathrm{H}, \mathrm{H}_{\alpha}+\mathrm{C}_{6} \mathrm{H}_{5}\right) \mathrm{ppm} .{ }^{31} \mathrm{P}\left\{{ }^{1} \mathrm{H}\right\}$ NMR: $35.4 \mathrm{ppm}$. FAB-MS: $\mathrm{m} / \mathrm{z}$ (\% abundance) 697 (6) [M $\left.\mathrm{O}_{2} \mathrm{CH}\right]^{+}, 670$ (1) $\left[\mathrm{M}-\text { alkenyl }-\mathrm{O}_{2} \mathrm{CH}\right]^{+}$. Anal. Found: C, 64.8; $\mathrm{H}$, 4.9. Calcd for $\mathrm{C}_{40} \mathrm{H}_{34} \mathrm{O}_{2} \mathrm{P}_{2}$ RuS: C, 64.8; H, 4.6.

Preparation of $\left[\mathbf{R u}\{\mathbf{C}(\mathbf{C} \equiv \mathbf{C P h})=\mathbf{C H P h}\}\left(\kappa^{2}-\mathrm{O}_{2} \mathbf{C F c}\right)(\mathrm{CS})\right.$ $\left.\left(\mathbf{P P h}_{3}\right)_{2}\right]$ (15). $\left[\mathrm{Ru}\{\mathrm{C}(\mathrm{C} \equiv \mathrm{CPh})=\mathrm{CHPh}\} \mathrm{Cl}(\mathrm{CS})\left(\mathrm{PPh}_{3}\right)_{2}\right](\mathbf{4} ; 150 \mathrm{mg}$, $0.165 \mathrm{mmol})$ was dissolved in dichloromethane $(10 \mathrm{~mL})$ and ferrocenecarboxylic acid (40 mg, $0.174 \mathrm{mmol}$ ) added, followed by 3 drops of triethylamine (excess). The solution darkened over 30 min of stirring. After $1 \mathrm{~h}$, ethanol $(10 \mathrm{~mL})$ was added and the solvent volume reduced on the rotary evaporator. The precipitated orange-yellow solid was isolated by filtration, washed with ethanol (5 mL) and hexane $(10 \mathrm{~mL})$, and dried. Yield: $160 \mathrm{mg}(88 \%)$. IR $\left(\mathrm{CH}_{2} \mathrm{Cl}_{2}\right): 2158 v_{\mathrm{C} \equiv \mathrm{C}}, 1504 v_{\mathrm{OCO}}, 1280 v_{\mathrm{CS}} \mathrm{cm}^{-1}$. IR (Nujol): 2154 $v_{\mathrm{C} \equiv \mathrm{C}}, 1594,1573,1544,1500 v_{\mathrm{OCO}}, 1270 v_{\mathrm{CS}}, 973,914,835,811$ $\mathrm{cm}^{-1}$. ${ }^{1} \mathrm{H}$ NMR: 3.49 (s, $\mathrm{C}_{5} \mathrm{H}_{5}$ ), 3.88 (pseudo-t, $2 \mathrm{H}, \mathrm{C}_{5} \mathrm{H}_{4}, J_{\mathrm{HH}}=$ 1.7), 4.03 (pseudo-t, $\left.\mathrm{C}_{5} \mathrm{H}_{4}, 2 \mathrm{H}, J_{\mathrm{HH}}=1.7\right), 5.85(\mathrm{t}, 1 \mathrm{H},=\mathrm{CH}$, $\left.J_{\mathrm{HP}}=1.7\right), 7.08-7.14\left(\mathrm{~m}, \mathrm{C}_{6} \mathrm{H}_{5}\right), 7.18-7.70\left(\mathrm{~m}, 30 \mathrm{H}, \mathrm{PC}_{6} \mathrm{H}_{5}+\right.$ $\left.\mathrm{C}_{6} \mathrm{H}_{5}\right)$ ppm. ${ }^{31} \mathrm{P}\left\{{ }^{1} \mathrm{H}\right\}$ NMR: 33.7 ppm. FAB-MS: $\mathrm{m} / z$ (\% abundance) 873 (4) $\left[\mathrm{M}-\mathrm{O}_{2} \mathrm{CFc}\right]^{+}, 669(2)\left[\mathrm{M}-\text { alkenyl }-\mathrm{O}_{2} \mathrm{CFc}\right]^{+}$, 407 (14) $\left[\mathrm{M}-\text { alkenyl }-\mathrm{O}_{2} \mathrm{CFc}-\mathrm{PPh}_{3}\right]^{+}$. Anal. Found: C, 64.6; $\mathrm{H}$, 4.4. Calcd for $\mathrm{C}_{62} \mathrm{H}_{50} \mathrm{FeO}_{2} \mathrm{P}_{2} \mathrm{RuS} \cdot \mathrm{CH}_{2} \mathrm{Cl}_{2}$ : C, 65.1; $\mathrm{H}$, 4.5.

Preparation of $\mathrm{Fe}\left[\mu-\eta^{5}: \kappa^{2}-\mathrm{C}_{5} \mathrm{H}_{4} \mathrm{CO}_{2} \mathrm{Ru}\{\mathrm{C}(\mathrm{C} \equiv \mathbf{C P h})=\mathbf{C H P h}\}\right.$ $\left.(\mathbf{C S})\left(\mathbf{P P h}_{3}\right)_{2}\right]_{2} \quad$ (16). $\left[\mathrm{Ru}\{\mathrm{C}(\mathrm{C} \equiv \mathrm{CPh})=\mathrm{CHPh}\} \mathrm{Cl}(\mathrm{CS})\left(\mathrm{PPh}_{3}\right)_{2}\right] \quad$ (4; $130 \mathrm{mg}, 0.143 \mathrm{mmol})$ was dissolved in dichloromethane $(10 \mathrm{~mL})$ and 1,1'-ferrocenedicarboxylic acid (20 mg, $0.073 \mathrm{mmol}$ ) added, followed by 3 drops of triethylamine (excess). The solution was stirred for $20 \mathrm{~h}$ and ethanol $(10 \mathrm{~mL})$ added. The solvent volume was reduced on the rotary evaporator. The precipitated yellow solid was isolated by filtration, washed with ethanol $(5 \mathrm{~mL})$ and petroleum ether $(10 \mathrm{~mL})$, and dried. Yield: $150 \mathrm{mg}(52 \%)$. IR $\left(\mathrm{CH}_{2} \mathrm{Cl}_{2}\right): 2156 v_{\mathrm{C} \equiv \mathrm{C}}, 1496 v_{\mathrm{OCO}}, 1280 v_{\mathrm{CS}} \mathrm{cm}^{-1}$. IR (Nujol): 2156 $v_{\mathrm{C} \equiv \mathrm{C}}, 1592,1492 v_{\mathrm{OCO}}, 1392,1357,1270 v_{\mathrm{CS}}, 973,912,835,809$ $\mathrm{cm}^{-1} .{ }^{1} \mathrm{H}$ NMR: 3.60 (pseudo-t, $\mathrm{C}_{5} \mathrm{H}_{4}, 8 \mathrm{H}, J_{\mathrm{HH}}=1.8$ ), $5.85(\mathrm{~s}$ (br), $2 \mathrm{H},=\mathrm{CH}), 7.46-7.71\left(\mathrm{~m}, 60 \mathrm{H}+20 \mathrm{H}, \mathrm{PC}_{6} \mathrm{H}_{5}+\mathrm{C}_{6} \mathrm{H}_{5}\right)$ ppm. ${ }^{13} \mathrm{C}\left\{{ }^{1} \mathrm{H}\right\}$ NMR $\left(1: 4 \mathrm{CDCl}_{3}-\mathrm{CH}_{2} \mathrm{Cl}_{2}\right): 302.5$ (t, CS, $J_{\mathrm{CP}}=$ $16.1), 180.8\left(\mathrm{~s}, \mathrm{O}_{2} \mathrm{C}\right), 142.4,139.6(\mathrm{~s} \times 2, \mathrm{C} \equiv \mathrm{CPh}), 135.0\left(\mathrm{t}^{\mathrm{v}}, o-/\right.$ $\left.m-\mathrm{PC}_{6} \mathrm{H}_{5}, J_{\mathrm{CP}}=5.4\right), 131.7\left(\mathrm{~s}, \mathrm{C}_{6} \mathrm{H}_{5}\right), 130.2\left(\mathrm{t}^{\mathrm{v}}, i-\mathrm{PC}_{6} \mathrm{H}_{5}, J_{\mathrm{CP}}=\right.$ 21.4), 129.8 (s, $\left.p-\mathrm{PC}_{6} \mathrm{H}_{5}\right), 128.1\left(\mathrm{~s}, \mathrm{C}_{6} \mathrm{H}_{5}\right), 127.6\left(\mathrm{t}^{\mathrm{v}}, o-/ m-\mathrm{PC}_{6} \mathrm{H}_{5}\right.$, $J_{\mathrm{CP}}$ unresolved), 126.9, 126.2, $124.7\left(\mathrm{~s} \times 3, \mathrm{C}_{6} \mathrm{H}_{5}\right), 76.0(\mathrm{~s}$, $\left.i-\mathrm{PC}_{5} \mathrm{H}_{4}\right), 70.0\left(\mathrm{~s}, o-/ m-\mathrm{C}_{5} \mathrm{H}_{4}\right), 68.7\left(\mathrm{~s}, o-/ m-\mathrm{C}_{5} \mathrm{H}_{4}\right) \mathrm{ppm} .{ }^{31} \mathrm{P}\left\{{ }^{1} \mathrm{H}\right\}$ NMR: $33.0 \mathrm{ppm}$. FAB-MS: $\mathrm{m} / \mathrm{z}$ (\% abundance) 2012 (28) [M $6]^{+}, 1757$ (30) $\left[\mathrm{M}-\mathrm{PPh}_{3}\right]^{+}, 1553(14)\left[\mathrm{M}-\text { alkenyl }-\mathrm{PPh}_{3}\right]^{+}$, 
Table 4. Crystal Data and Data Collection and Refinement Parameters for Compounds 1, 4, 11, 15, and 16 ${ }^{a}$

\begin{tabular}{|c|c|c|c|c|c|}
\hline & 1 & 4 & 11 & 15 & 16 \\
\hline chem formula & $\mathrm{C}_{51} \mathrm{H}_{41} \mathrm{ClP}_{2} \mathrm{RuS}$ & $\mathrm{C}_{53} \mathrm{H}_{41} \mathrm{ClP}_{2} \mathrm{RuS}$ & $\mathrm{C}_{54} \mathrm{H}_{41} \mathrm{ClOP}_{2} \mathrm{RuS}$ & $\mathrm{C}_{64} \mathrm{H}_{50} \mathrm{FeO}_{2} \mathrm{P}_{2} \mathrm{RuS}$ & $\mathrm{C}_{118} \mathrm{H}_{90} \mathrm{FeO}_{4} \mathrm{P}_{4} \mathrm{Ru}_{2} \mathrm{~S}_{2}$ \\
\hline solvent & $\mathrm{CHCl}_{3}$ & $\mathrm{CH}_{2} \mathrm{Cl}_{2}$ & $\mathrm{EtOH}$ & $\mathrm{CHCl}_{3}$ & $2 \mathrm{Et}_{2} \mathrm{O}$ \\
\hline formula wt & 1003.73 & 993.38 & 982.46 & 1221.33 & 2166.13 \\
\hline temp $(\mathrm{K})$ & $293(2)$ & 150 & $293(2)$ & $293(2)$ & $293(2)$ \\
\hline cryst color, habit & orange prismatic blocks & orange blocks & deep red blocks & orange rhomboids & orange blocks \\
\hline cryst size (mm) & $0.40 \times 0.37 \times 0.13$ & $0.10 \times 0.14 \times 0.18$ & $0.22 \times 0.14 \times 0.12$ & $0.40 \times 0.38 \times 0.22$ & $0.23 \times 0.20 \times 0.10$ \\
\hline cryst syst & orthorhombic & triclinic & monoclinic & orthorhombic & monoclinic \\
\hline space group & $P 2_{1} 2_{1} 2_{1}$ (No. 19 ) & $P \overline{1}$ (No. 2) & $P 2_{1}$ (No. 4 ) & Pbca (No. 61) & $I 2 / a($ No. 15$)$ \\
\hline$a(\AA)$ & $12.9182(18)$ & $12.1475(2)$ & $11.8799(8)$ & $22.7759(19)$ & $24.287(3)$ \\
\hline$b(\AA)$ & $17.933(2)$ & $12.2581(2)$ & $17.3422(9)$ & $18.791(4)$ & $13.5739(12)$ \\
\hline$c(\AA)$ & $20.0578(17)$ & $18.0528(3)$ & $12.0943(11)$ & $26.845(3)$ & $34.451(10)$ \\
\hline$\alpha(\mathrm{deg})$ & & $75.0004(7)$ & & & \\
\hline$\beta(\operatorname{deg})$ & & $78.8495(7)$ & $102.544(7)$ & & $95.559(10)$ \\
\hline$\gamma(\mathrm{deg})$ & & $63.7609(10)$ & & & \\
\hline$V\left(\AA^{3}\right)$ & 4646.6 & $2319.31(7)$ & $2432.2(3)$ & $11489(3)$ & $11304(4)$ \\
\hline$Z$ & 4 & 2 & 2 & 8 & $4^{b}$ \\
\hline$D_{\mathrm{c}}(\mathrm{g} / \mathrm{mL})$ & 1.435 & 1.442 & 1.341 & 1.412 & 1.273 \\
\hline radiation used & Mo K $\alpha$ & Mo K $\alpha$ & $\mathrm{Cu} \mathrm{K} \alpha$ & Mo K $\alpha$ & $\mathrm{Cu} \mathrm{K \alpha}$ \\
\hline$\mu(\mathrm{Mo} \mathrm{K} \alpha)\left(\mathrm{mm}^{-1}\right)$ & 0.717 & 0.662 & 4.452 & 0.791 & 4.447 \\
\hline $2 \theta_{\mathrm{max}} / \mathrm{deg}$ & 50 & & 120 & 50 & 120 \\
\hline no. of unique rflns measd & 4548 & 10505 & 3750 & 10104 & 8214 \\
\hline no. of obsd rflns $\left|F_{\mathrm{o}}\right|>4 \sigma\left(\left|F_{\mathrm{o}}\right|\right)$ & 3369 & 6508 & 3531 & 5848 & 5098 \\
\hline no. of variables & 462 & 550 & 488 & 629 & 547 \\
\hline $\mathrm{R} 1, \mathrm{wR} 2^{c}$ & $0.040,0.082$ & $0.044,0.051$ & $0.047,0.125$ & $0.061,0.132$ & $0.075,0.186$ \\
\hline
\end{tabular}

${ }^{a}$ Details in common: graphite-monochromated radiation, refinement based on $F^{2} .{ }^{b}$ The complex has crystallographic $C_{2}$ symmetry. ${ }^{c} \mathrm{R} 1=\sum \| F_{\mathrm{o}} \mid-$ $\left|F_{\mathrm{c}}\right|\left|/ \sum\right| F_{\mathrm{o}} \mid ; \mathrm{wR} 2=\left\{\sum\left[w\left(F_{\mathrm{o}}^{2}-F_{\mathrm{c}}^{2}\right)^{2}\right] / \sum\left[w\left(F_{\mathrm{o}}{ }^{2}\right)^{2}\right]\right\}^{1 / 2} ; w^{-1}=\sigma^{2}\left(F_{\mathrm{o}}^{2}\right)+(a P)^{2}+b P$.

$1492(55)\left[\mathrm{M}-2 \mathrm{PPh}_{3}\right]^{+}, 1231(100)\left[\mathrm{M}-3 \mathrm{PPh}_{3}\right]^{+}, 1146(64)$ $\left[\mathrm{M}-\mathrm{Ru}-\mathrm{CS}-\text { alkenyl }-2 \mathrm{PPh}_{3}\right]^{+}$. Anal. Found: C, 68.0; $\mathrm{H}$, 4.4. Calcd for $\mathrm{C}_{118} \mathrm{H}_{90} \mathrm{FeO}_{4} \mathrm{P}_{4} \mathrm{Ru}_{2} \mathrm{~S}_{2} \cdot \mathrm{CH}_{2} \mathrm{Cl}_{2}$ : C, 68.0; $\mathrm{H}$, 4.4.

Crystallography. Single crystals of complexes $1,4,11,15$, and 16 were obtained by slow diffusion of ethanol into solutions of the complexes in dichloromethane, and these were mounted on glass fibers for data collection. Table 4 provides a summary of the crystallographic data for compounds $1,4,11,15$, and 16 . Data were collected using Siemens P4 (1 and 15) and Enraf-Nonius KappaCCD (4) and P4/RA (11 and 16) diffractometers, and the structures were refined on the basis of $F^{2}$ using the SHELXTL and SHELX-97 program systems. ${ }^{43}$ The absolute structures of $\mathbf{1}$ and 11 were determined by a combination of $R$ factor tests (for $1 \mathrm{R} 1^{+}$ $=0.0404$ and $\mathrm{R} 1^{-}=0.0426$; for $11 \mathrm{R} 1^{+}=0.0468$ and $\mathrm{R} 1^{-}=$ 0.0506 ) and by use of the Flack parameter (for $1 x^{+}=+0.00(5)$ and $x^{-}=+1.14(5)$; for $11 x^{+}=+0.15(3)$ and $x^{-}=+0.85(3)$ ). Intensity data for 4 were processed using the DENZO-SMN package, ${ }^{44}$ and the structure was solved using the direct-methods program SIR92, ${ }^{45}$ which located all non-hydrogen atoms. Subsequent full-matrix least-squares refinement was carried out using the CRYSTALS program suite. ${ }^{46}$ Coordinates and anisotropic thermal parameters of all non-hydrogen atoms were refined.

(43) SHELXTL PC, version 5.1; Bruker AXS, Madison, WI, 1997. Sheldrick, G. SHELX-97; Institut Anorganische Chemie, Tammannstr. 4, D-37077 Göttingen, Germany, 1998.

(44) Otwinowski, Z.; Minor, W. Processing of X-ray Diffraction Data Collected in Oscillation Mode. Methods Enzymol. 1997, 276.

(45) Altomare, A.; Cascarano, G.; Giacovazzo, G.; Guagliardi, A.; Burla, M. C.; Polidori, G.; Camalli, M. J. Appl. Crystallogr. 1994, 27, 435.
Hydrogen atoms were positioned geometrically after each cycle of refinement. A three-term Chebychev polynomial weighting scheme was applied. The crystallographic data for the structures of $\mathbf{1 , 4}$, 11, 15, and 16 have been deposited with the Cambridge Crystallographic Data Centre as supplementary publication numbers CCDC 637444-637448, respectively. Copies of the data can be obtained free of charge on application to The Director, CCDC, 12 Union Road, Cambridge CB2 1EZ, U.K. (fax, int. code +44 (1223) 336033; e-mail for inquiry, fileserv@ccdc.cam.ac.uk).

Acknowledgment. We are grateful to the EPSRC (U.K.) for funding and diffractometry equipment. A.F.H. wishes to thank the Department of Chemistry, University of Auckland, for the provision of research facilities, Johnson Matthey Chemicals Ltd for a generous loan of ruthenium salts, and the Australian Research Council (Grant No. DP0556236) for financial support. J.D.E.T.W.-E. wishes to acknowledge Merton College, Oxford, U.K., for the provision of a fellowship.

Supporting Information Available: CIF files giving full details of the crystal structure determinations of 1, 4, 11, 15, and 16 . This material is available free of charge via the Internet at http://pubs.acs.org.

\section{OM700518M}

(46) Betteridge, P. W.; Cooper, J. R.; Cooper, R. I.; Prout, K.; Watkin, D. J. CRYSTALS, Issue 12. J. Appl. Crystallogr. 2003, 36, 1487. 